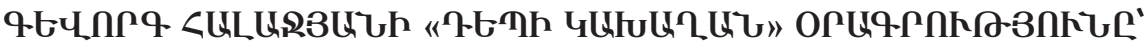

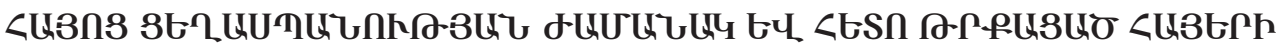

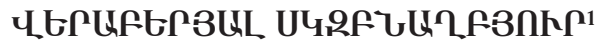

\section{Lium $U$. Ohminquinjuin

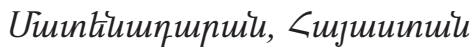

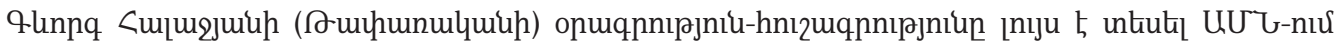

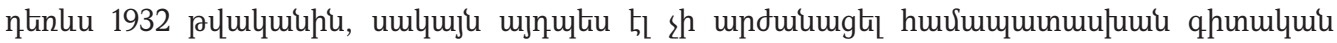

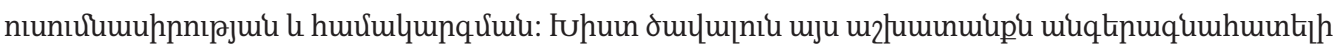

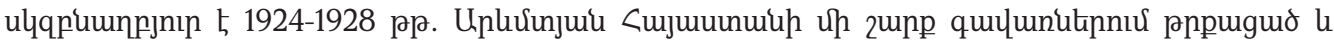

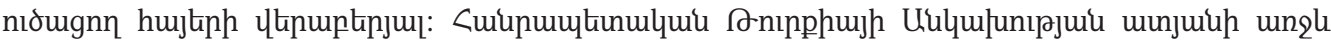

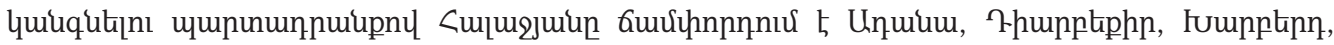

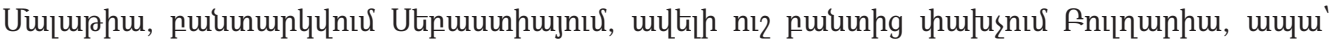
Uútiphluw:

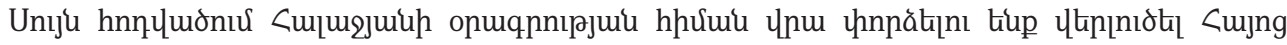

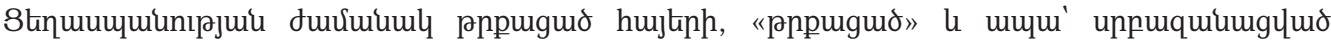

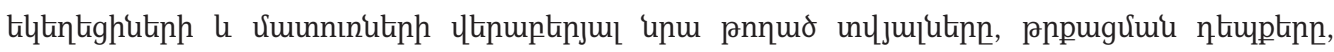

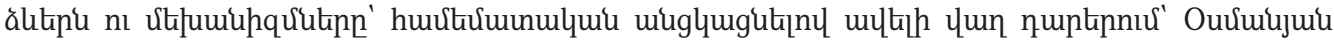

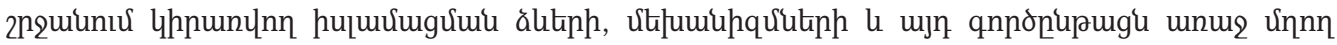

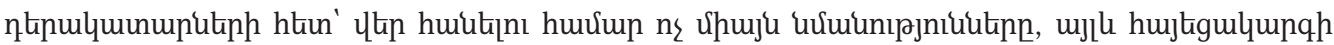

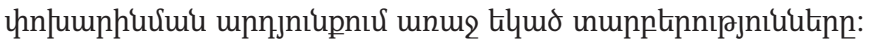

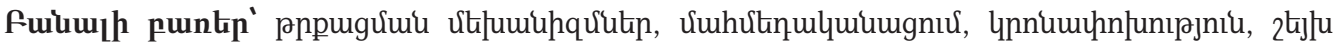

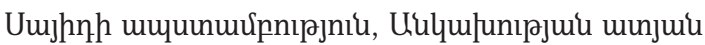

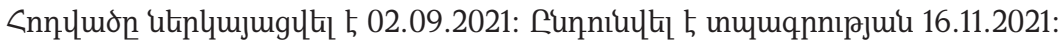

The article was submitted on 02.09.2021 and accepted for publication on 16.11.2021.

Статья поступила 02.09.2021 и была принята к публикации 16.11.2021.

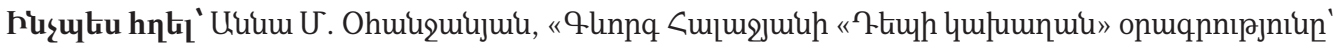

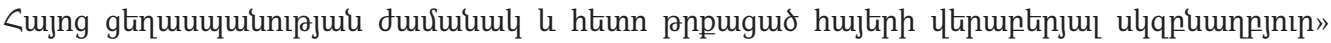

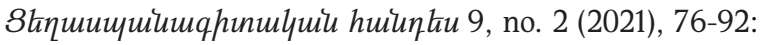

How to cite: Anna M. Ohanjanyan, “Gevorg Halajyan's diary 'To the Gallows' as a Primary Source on Turkified Armenians during and after the Armenian Genocide," Ts'eghaspanagitakan handes 9, no. 2 (2021): 76-92.

Как ссылаться: Анна М. Оганджанян, “Дневник Геворга Аладжяна 'На виселицу' как первоисточник о тюркизированных армянах во время и после Геноцида армян,” Тсехаспанагитакан андес 9, по. 2 (2021): 76-92.

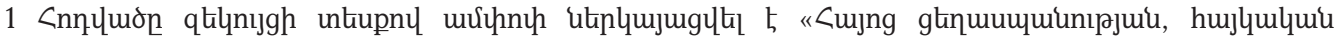

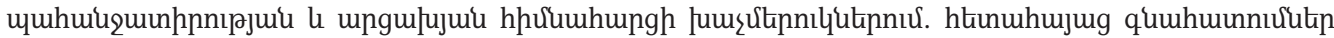

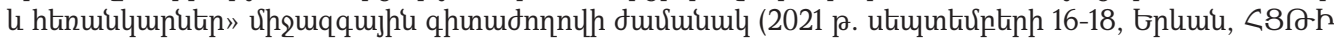

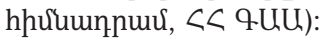




\section{Utipudnıpjnitu}

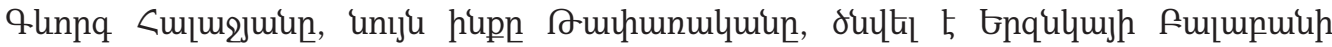

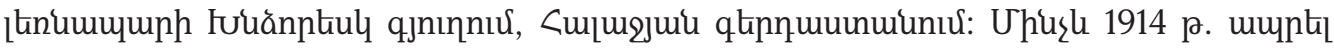

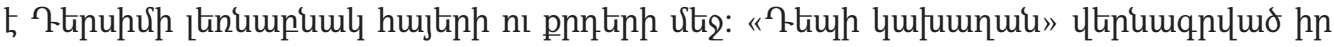

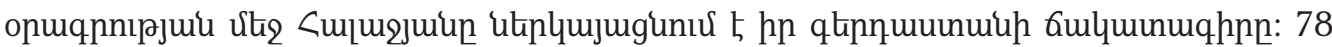

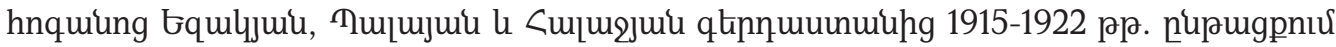

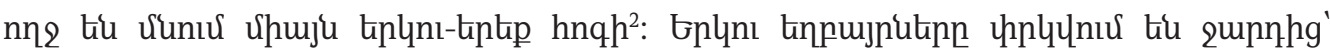

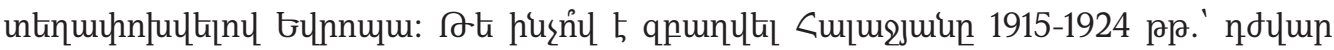

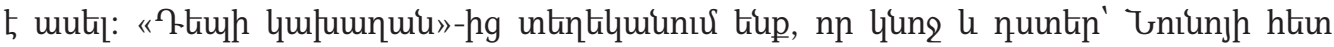

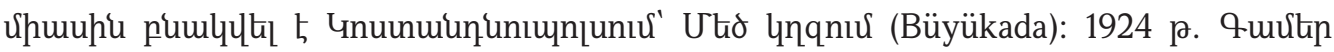

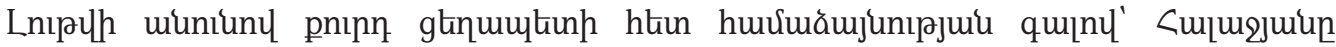

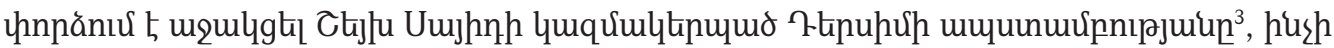

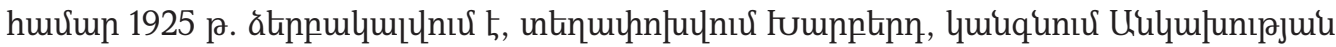

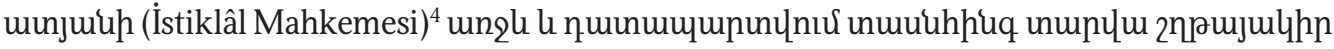

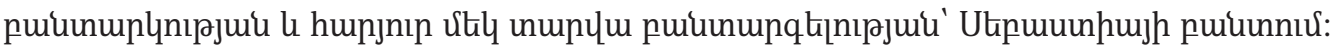

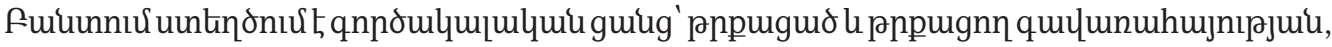

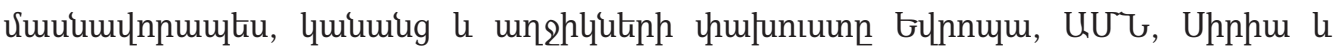

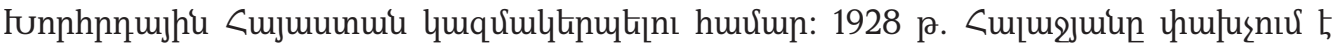

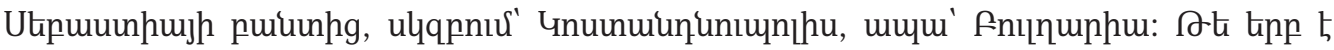
ulilutil UU

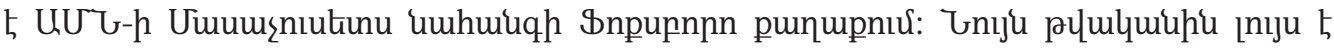

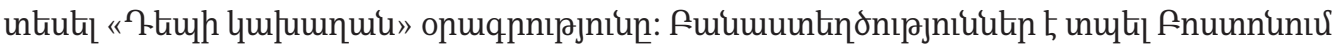

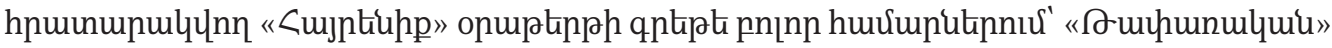

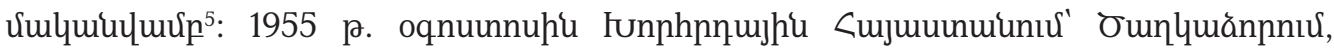

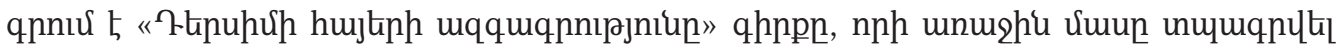

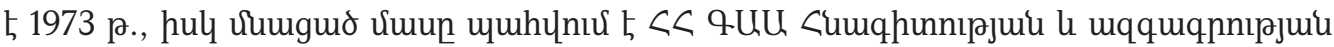

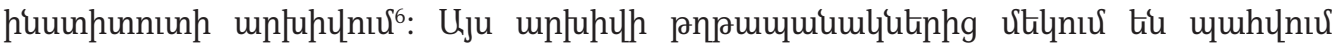

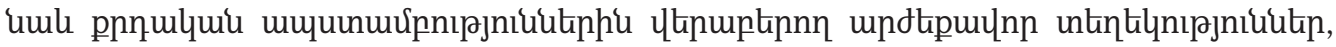

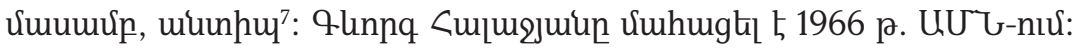

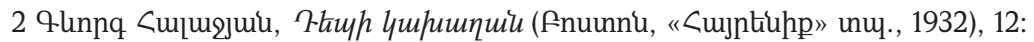

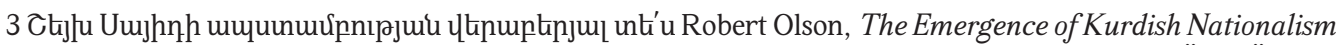
and the Sheikh Said Rebellion, 1880-1925 (Austin, TX: University of Texas Press, 1989); Uğur Ümit Üngör, The Making of Modern Turkey: Nation and State in Eastern Turkey 1913-1950 (Oxford: Oxford University Press, 2011), 122-148.

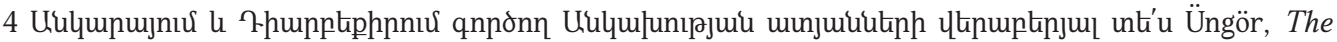
Making of Modern Turkey, 127-130:

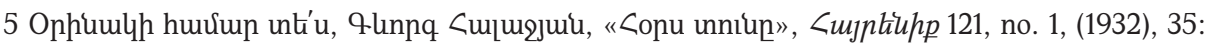

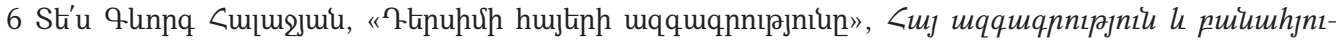

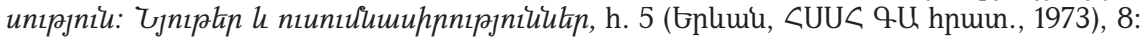

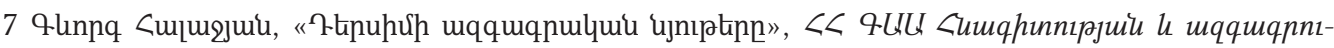




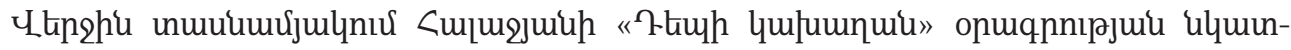

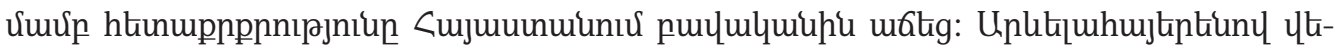

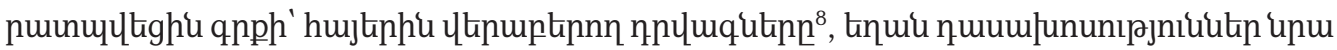

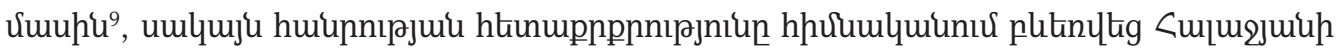

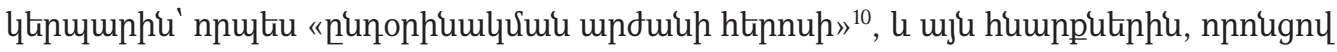

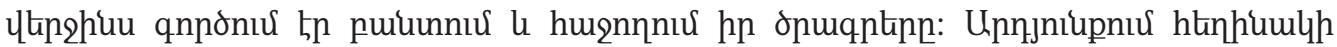

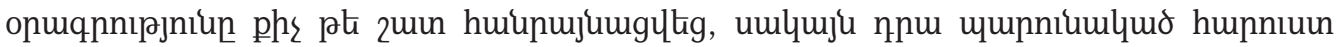

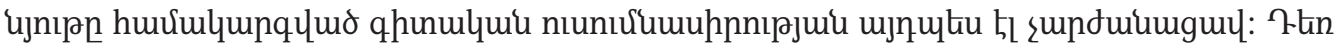

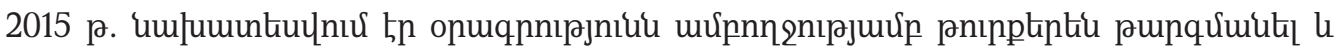

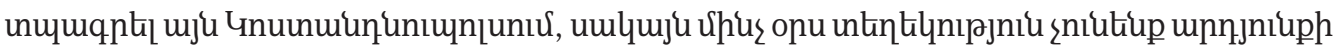

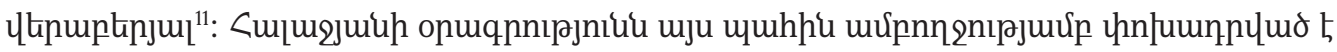

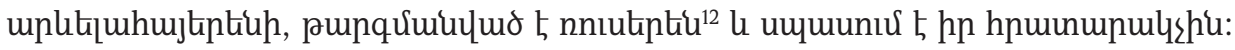

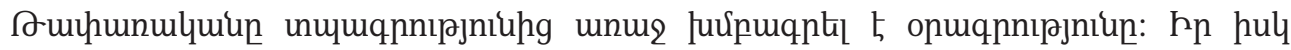

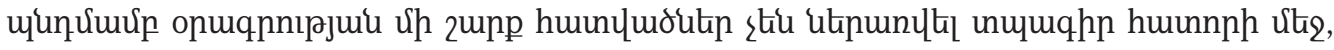

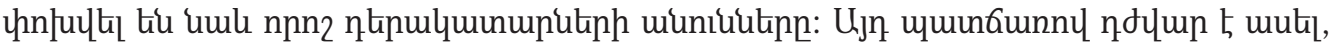

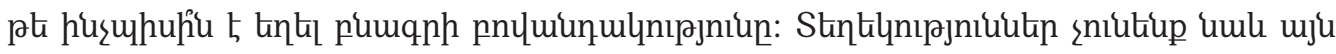

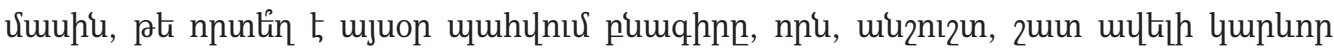

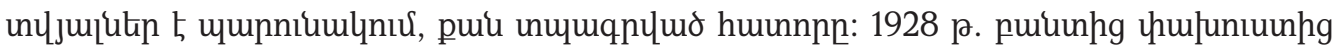

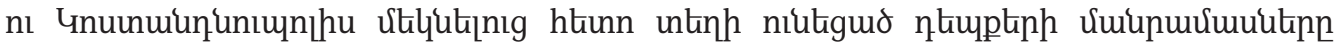

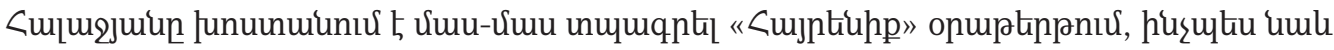

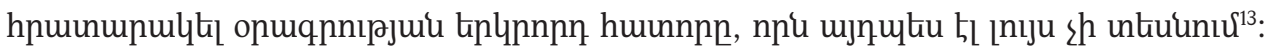

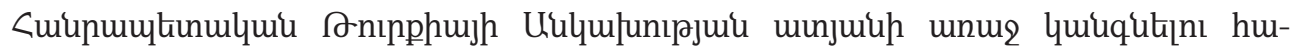

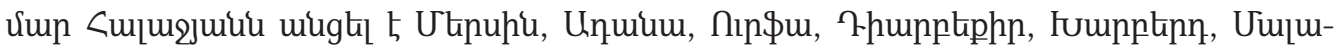

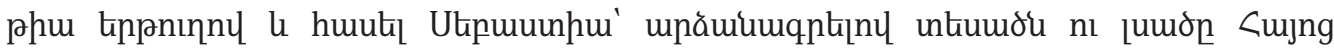

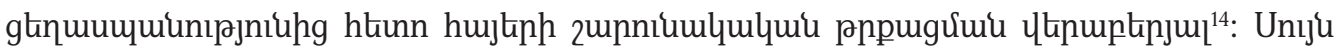

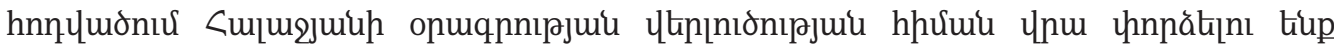

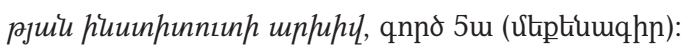

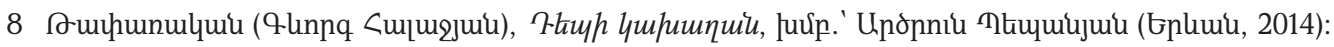

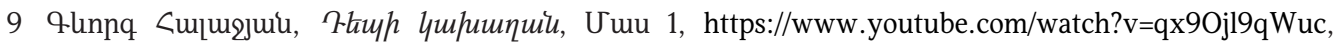
nhunltal 5 18.10.2021:

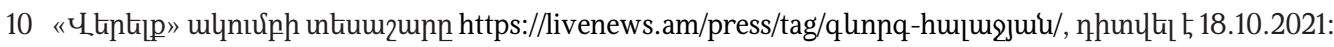

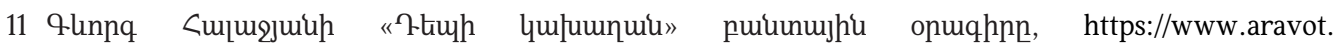
am/2015/03/05/548207/, nhunцtil 5 21.10.2021

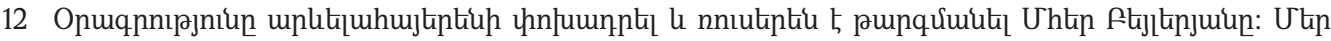

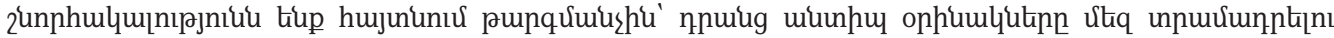
huviun:

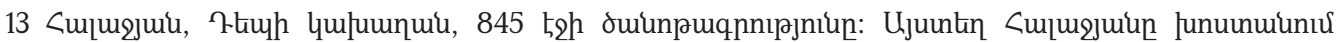

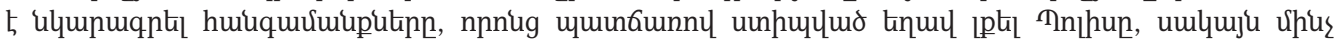

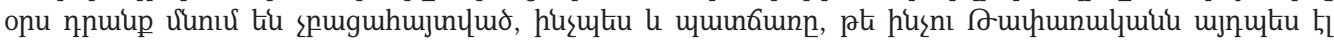

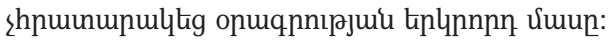

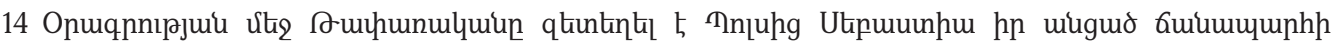

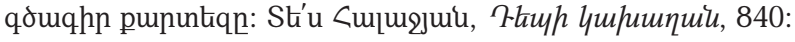




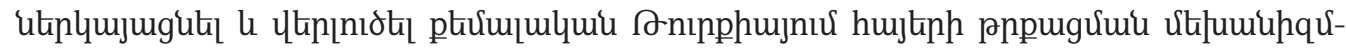

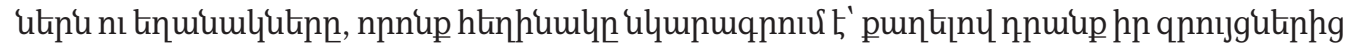

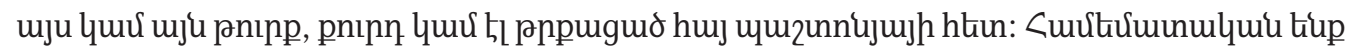

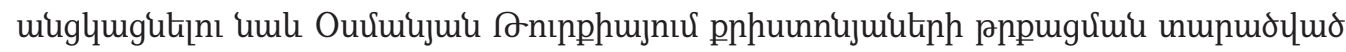

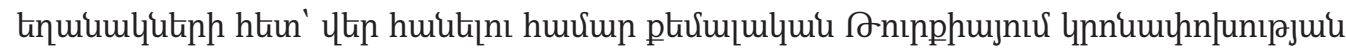
hujtgumumph \}umpưưuutinn:

\section{<ujkph pppugưuitu utijumihqưtutpn}

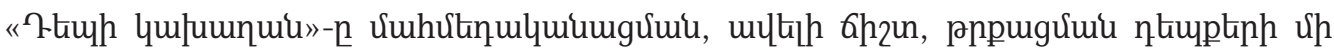

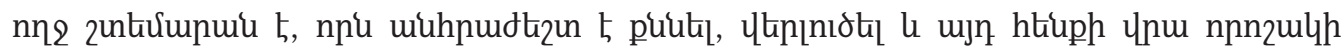

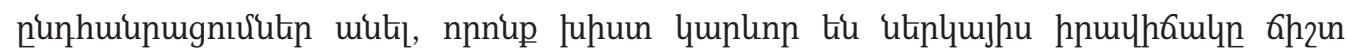

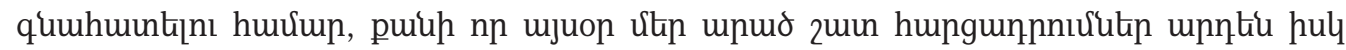

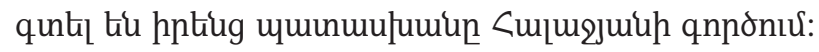

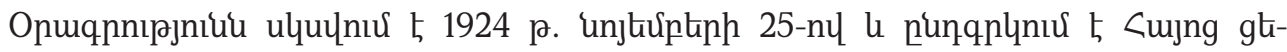

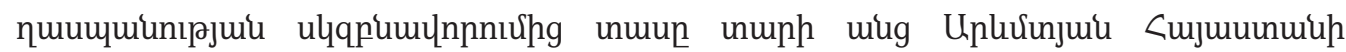

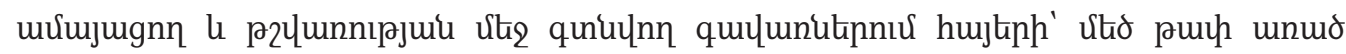

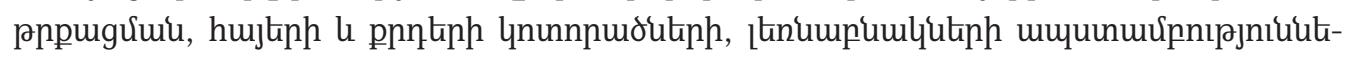

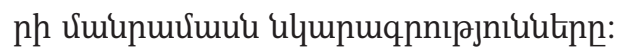

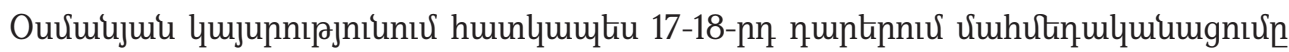

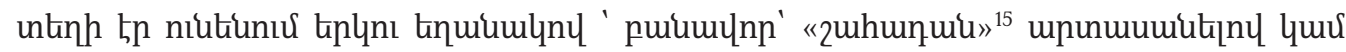

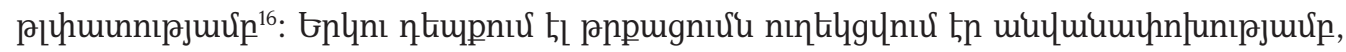

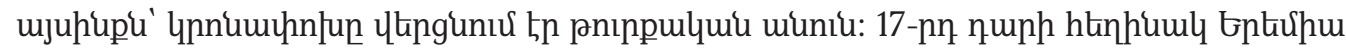

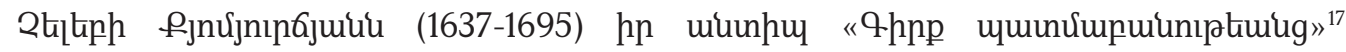

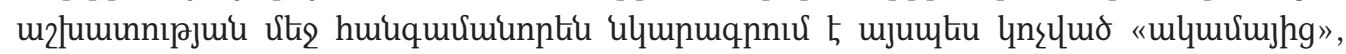

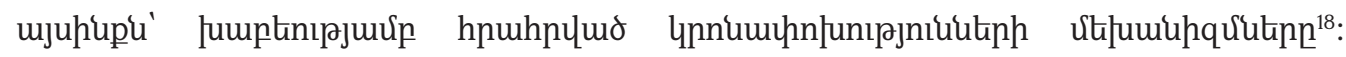

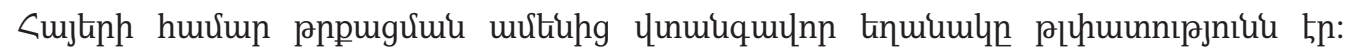

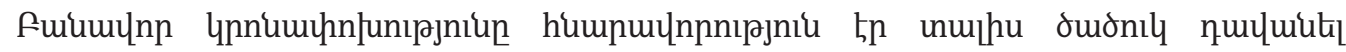

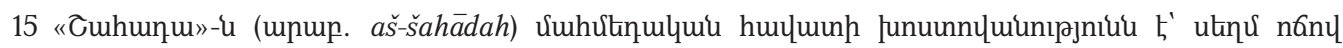

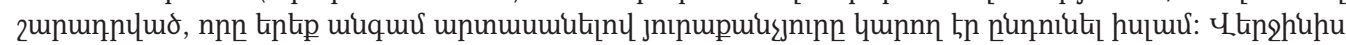

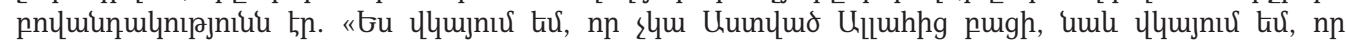

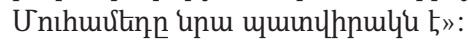

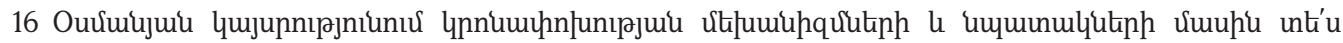
Marc David Baer, Honored by the Glory of Islam (Oxford: Oxford University Press, 2008); Tijana Krstić, Contested Conversions to Islam: Narratives of Religious Change in the Early Modern Ottoman Empire (Stanford, CA: Stanford University Press, 2011).

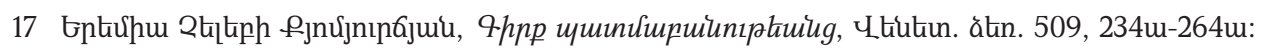

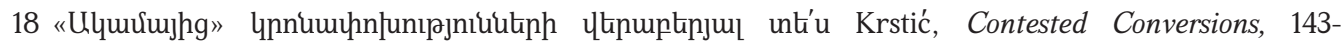

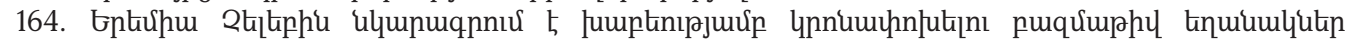

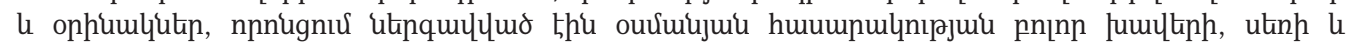

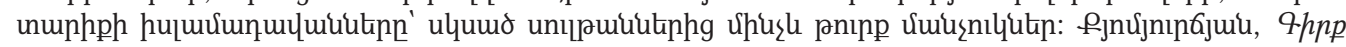
uminumpuiunstaming: 


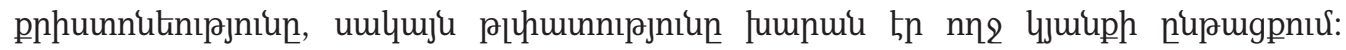

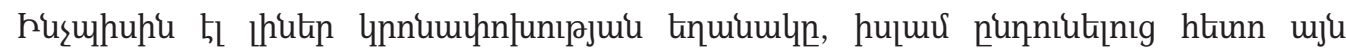

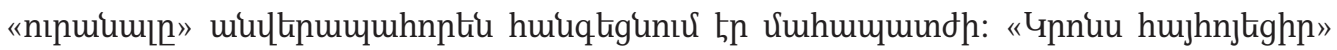

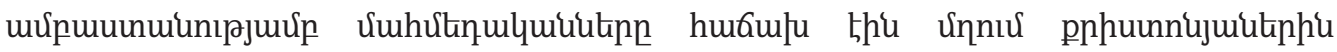

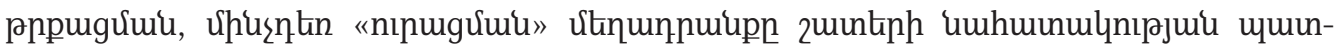

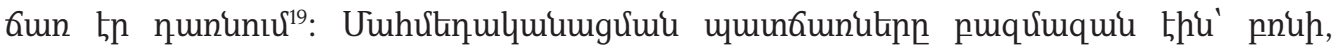

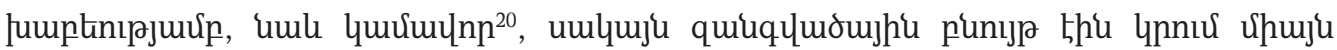

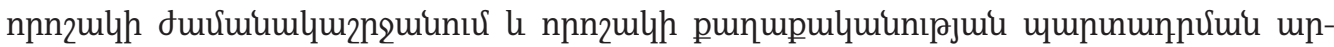

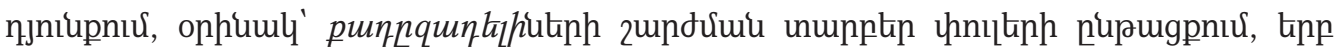

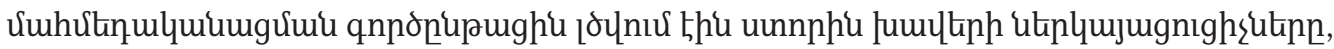

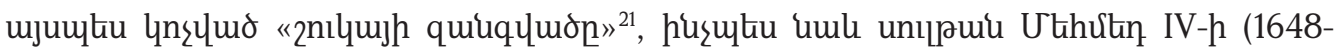

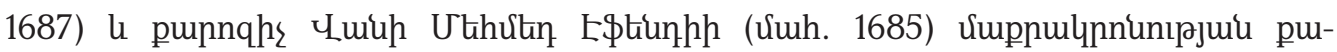

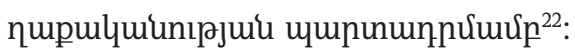

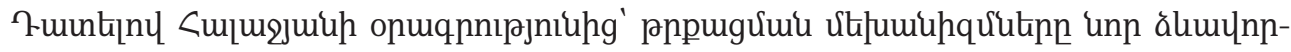

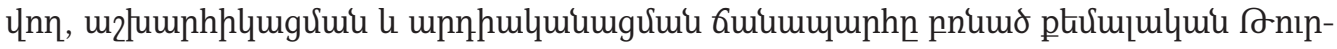

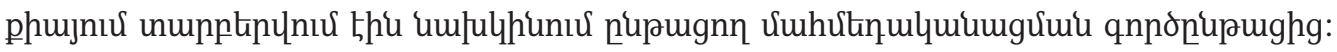

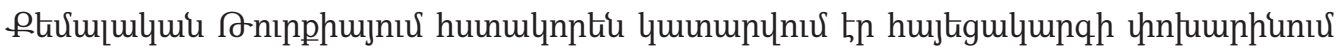

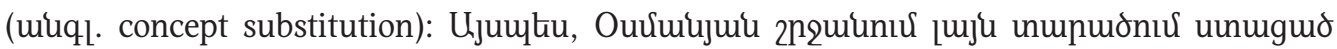

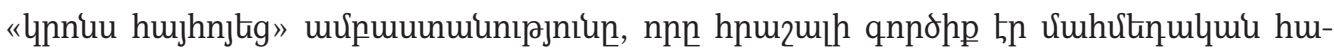

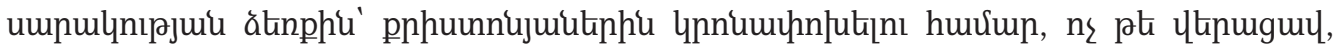

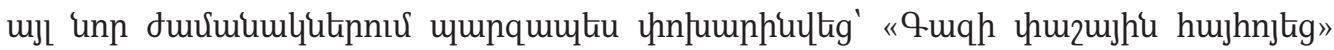

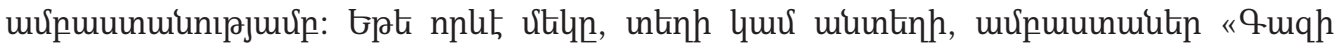

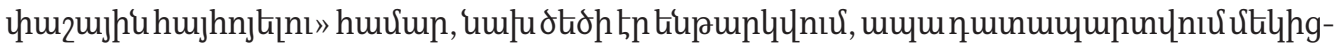

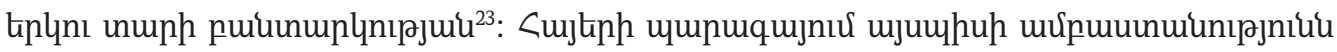

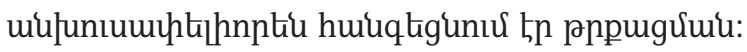

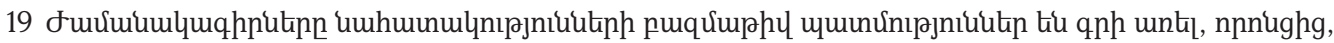

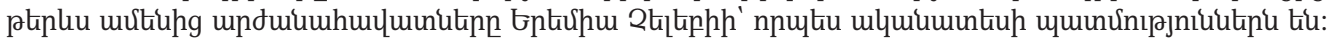

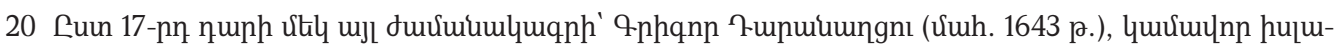

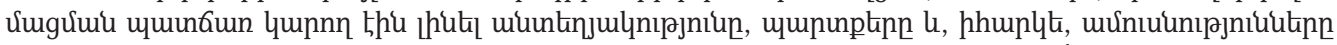

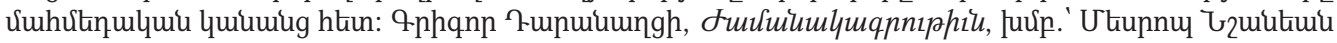
(Gpniuuntiu: Up. Bulynptiuing unu., 1915):

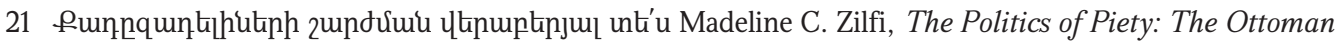
Ulema in the Post Classical Age (Minneapolis: Bibliotheca Islamica, 1988), 129-182. Idem, "The Kadizadelis: Discordant Revivalism in the Seventeenth-Century Istanbul," Journal of Near Eastern Studies 45, no. 4

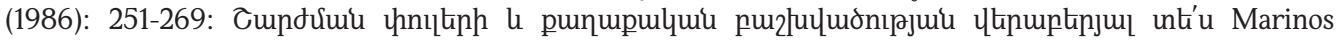
Sariyannis, "The Kadizadeli movement as a Social and Political Phenomenon: the Rise of a Mercantile Ethic?" in Political Initiatives from the Bottom-Up in the Ottoman Empire (Halcyon Days in Crete VII, A Symposium Held in Rethymno, 9-11 January 2009), ed. A. Anastasopoulos (Rethymno: Crete University Press, 2012), 263-289; Ekin Tuşalp Atiyas, “The 'Sunna-Minded' Trend," in A History of Ottoman Political Thought up to the Early Nineteenth Century (Handbook of Oriental Studies. Section 1 The Near and Middle East), vol. 125 (Leiden: Brill 2018), 233-278.

22 Baer, Honored by the Glory, 105-119.

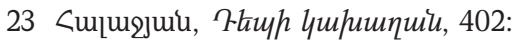




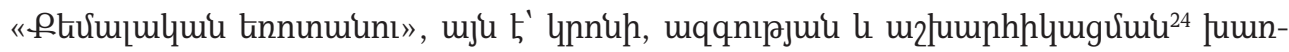

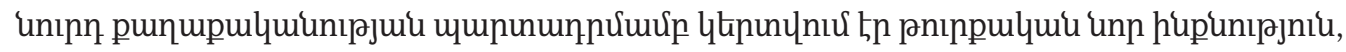

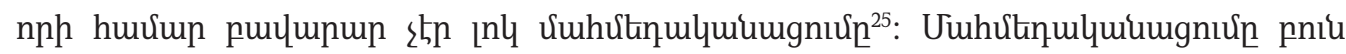

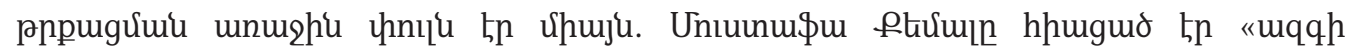

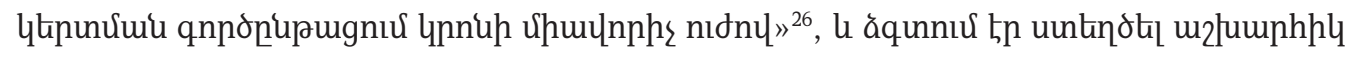

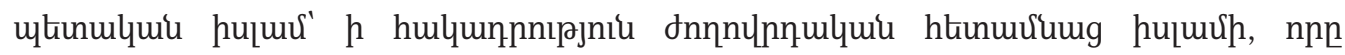

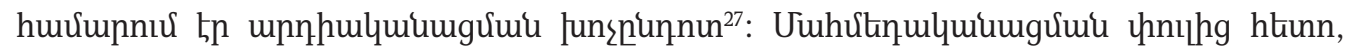

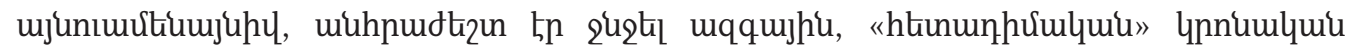

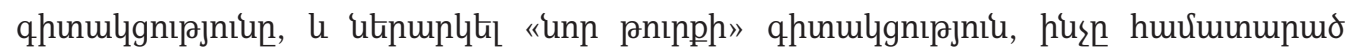

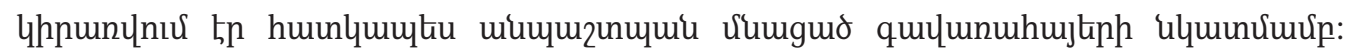

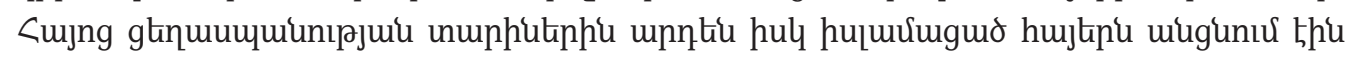

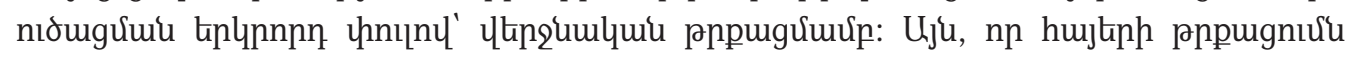

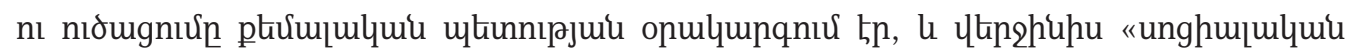
hudtuknhuugh» (muql. social engineerig) luphnn phnuluutphg utiln, huunul

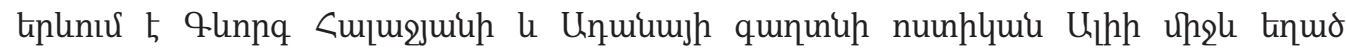

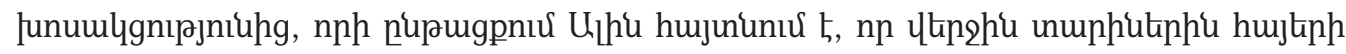

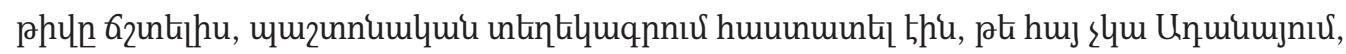

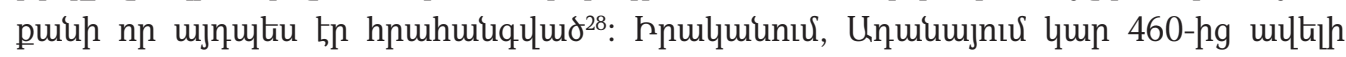

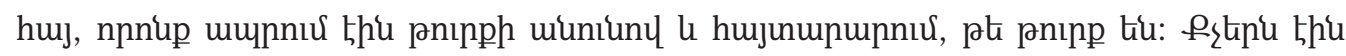

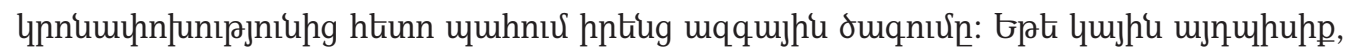

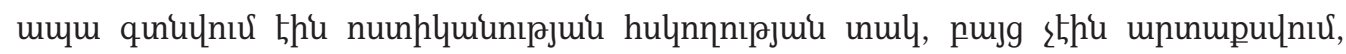

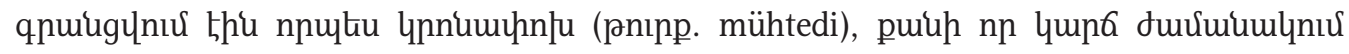

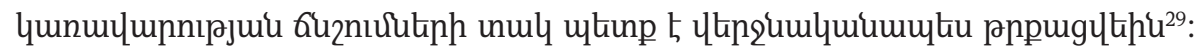

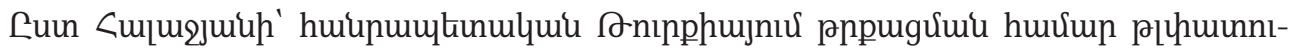

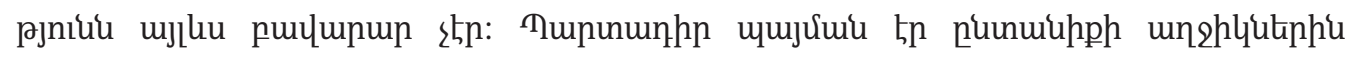

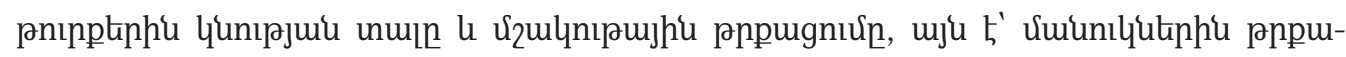

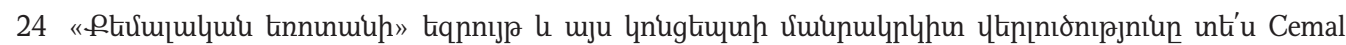
Karakas, "Turkey: Islam and Laicism between the Interests of State, Politics, and Society," PRIF Reports 78 (2007): 8-19.

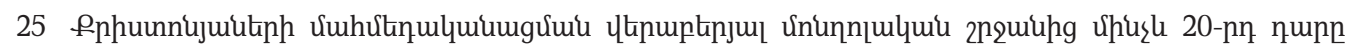
unt'u A.C.S. Peacock, Bruno De Nicola, Sara Nur Yildiz, "Introduction," in Islam and Christianity in Medieval Anatolia, eds. A.C.S. Peacock, et. al (London and New York: Routledge, 2016), 1-20.

26 Karakas, Turkey: Islam and Laicism, 8.

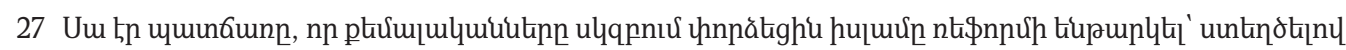

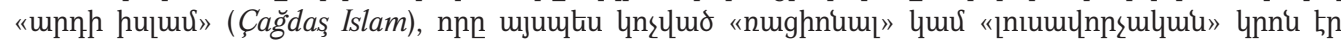

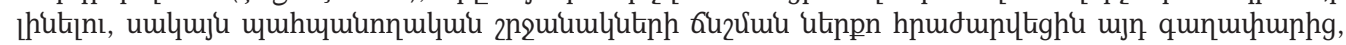

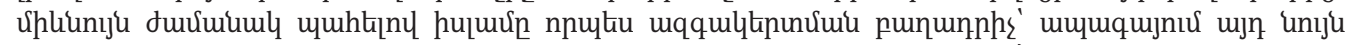

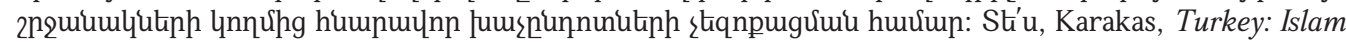
and Laicism, 10-11. Cungh puuunlnnự unt'u uuulu Lerna Ekmekçioğlu, Recovering Armenia: The Limits of Belonging in Post-Genocide Turkey (Stanford: Stanford University Press, 2016), 103-109.

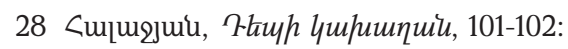

29 tnıju untinnu, 102: 


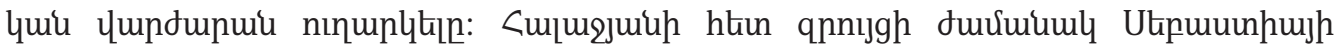

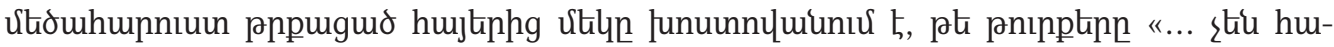

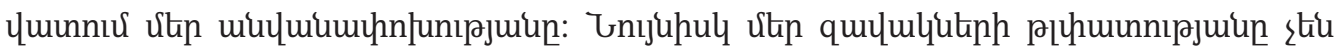

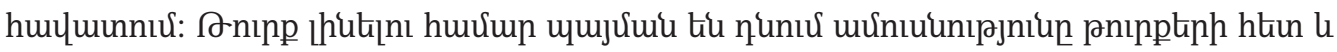

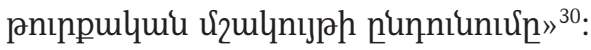

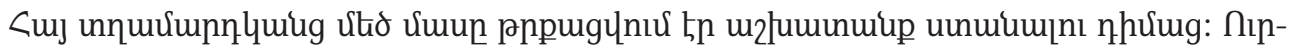

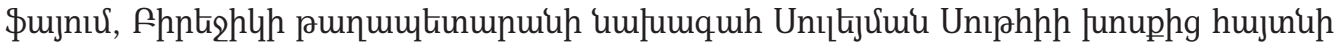

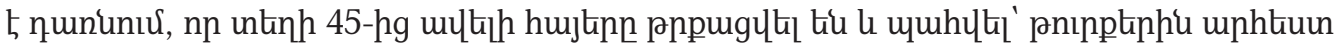

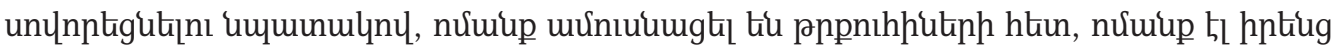

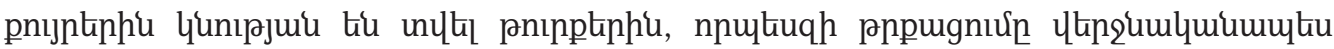

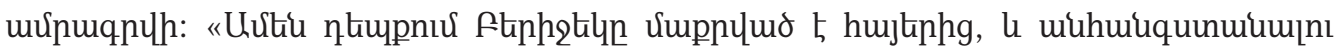

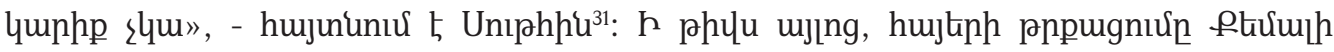

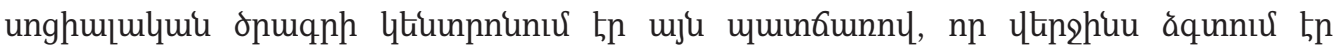

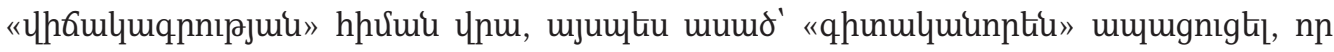

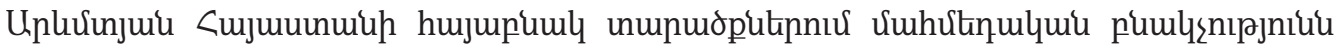

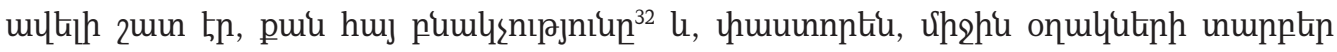

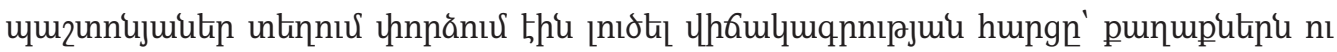

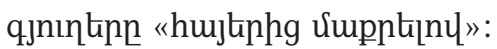

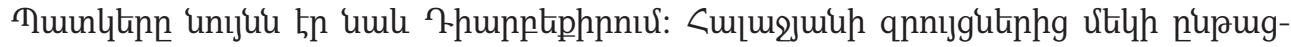

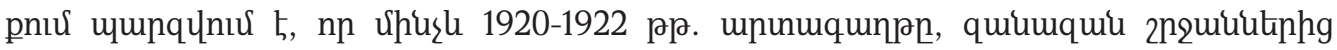

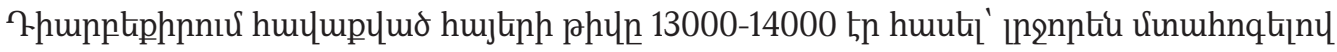

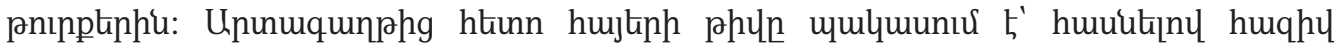

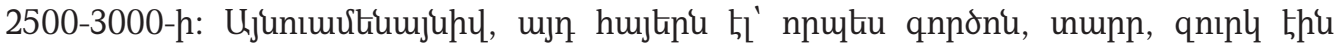

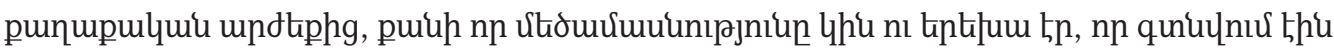

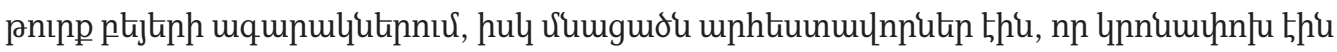

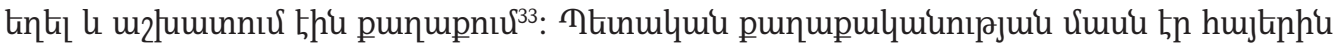

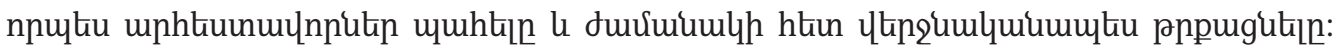

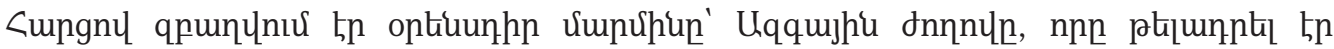

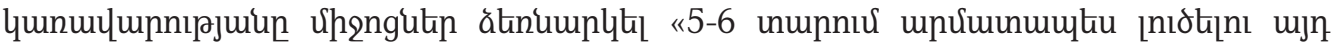

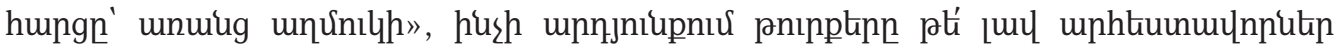

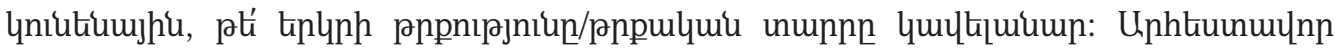

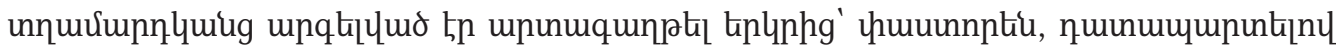

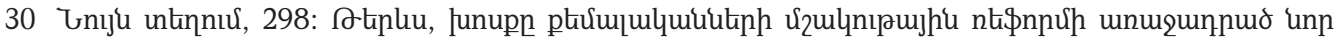

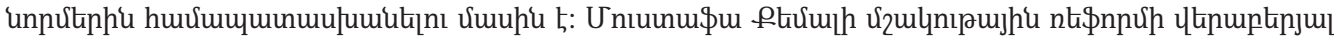

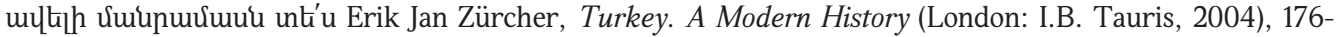
205.

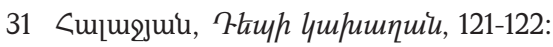

32 Fatma Ülgen, "Reading Mustafa Kemal Atatürk on the Armenian Genocide of 1915," Patterns of Prejudice 44, no. 4 (2010): 376. Stíu uulu Ekmekçioğlu, Recovering Armenia, 33:

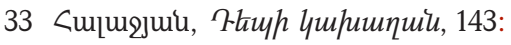




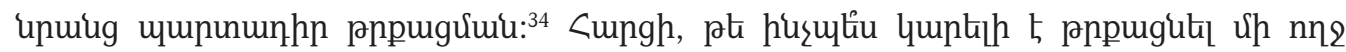

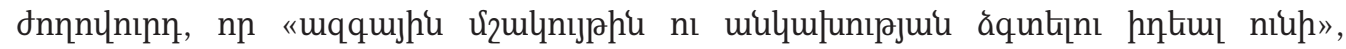

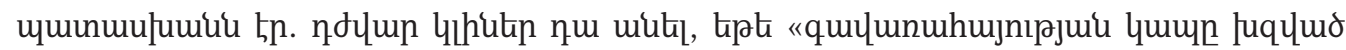
slhutip unumuphu w2lumphh htun» ${ }^{35}$ :

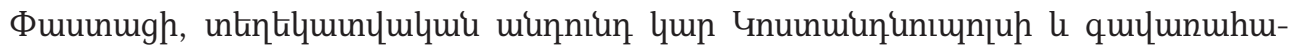

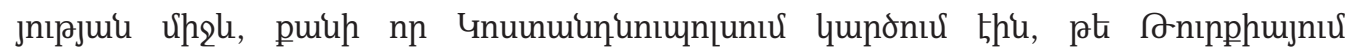

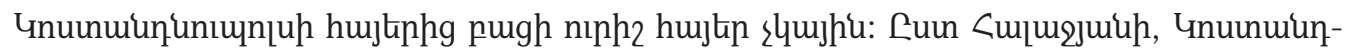

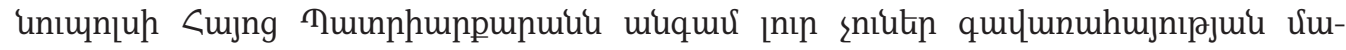

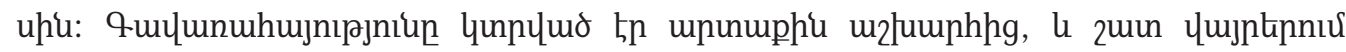

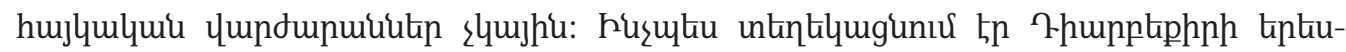

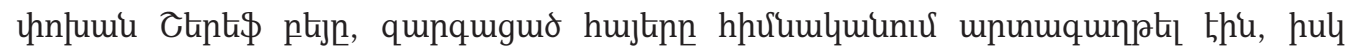

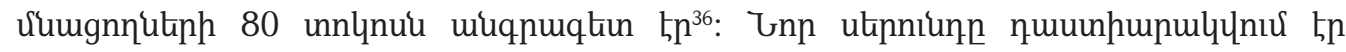

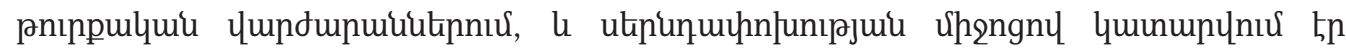

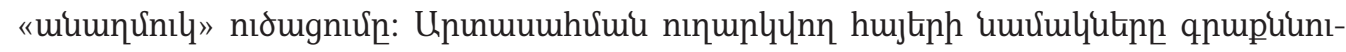

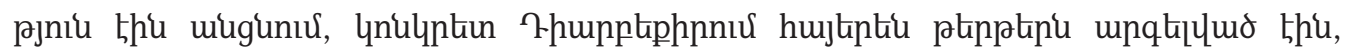

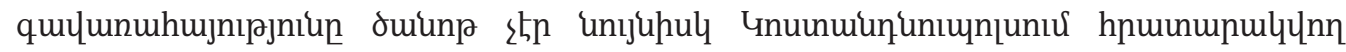

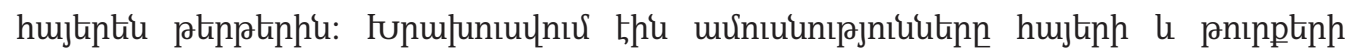

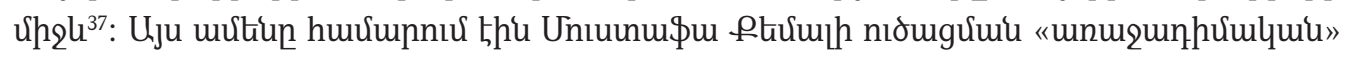

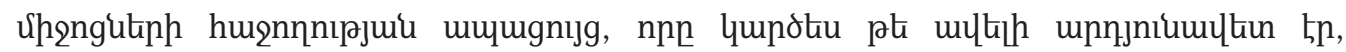

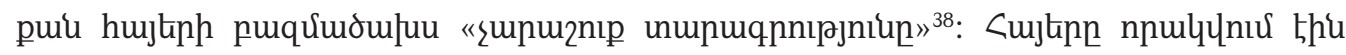

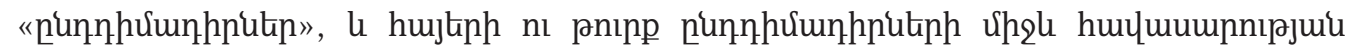

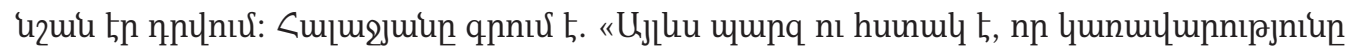

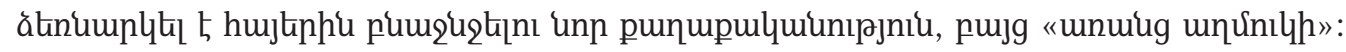

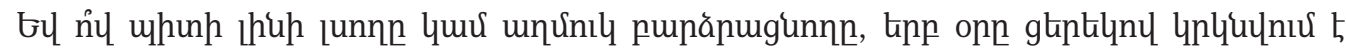
1915-h Gntinup » ${ }^{39}$ :

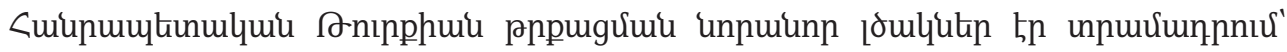

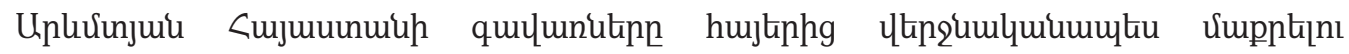

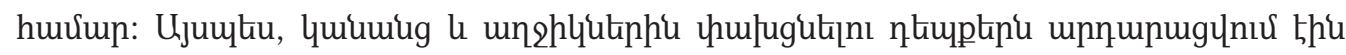

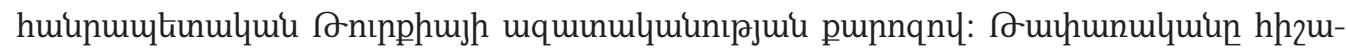

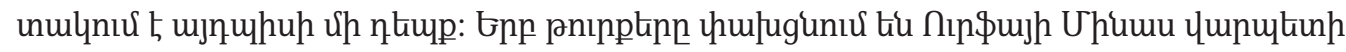

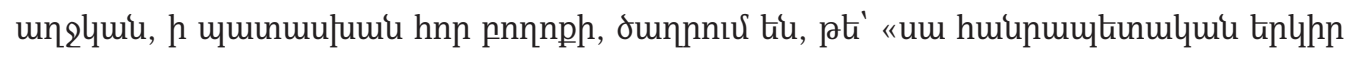

34 টnıju unŁnnux, 144:

35 টnıju unknnux:

36 ษnıju unknnıx:

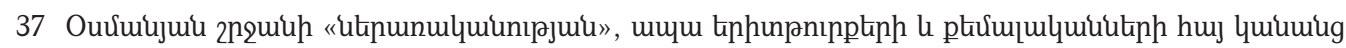

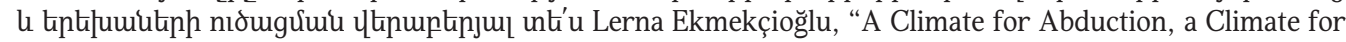
Redemption: The Politics of Inclusion during and after the Armenian Genocide," Comparative Studies in Society and History 55, no. 3 (2013): 522-553.

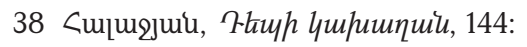

39 tnıju unknnux: 


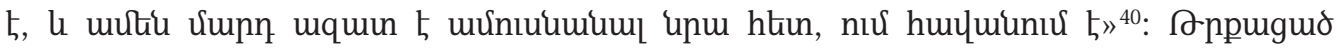

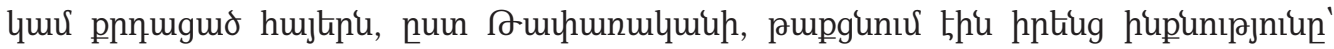

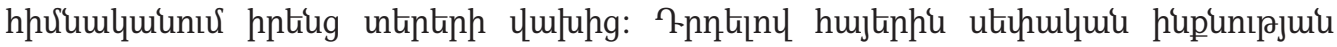

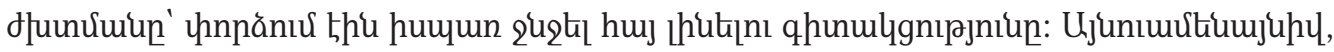

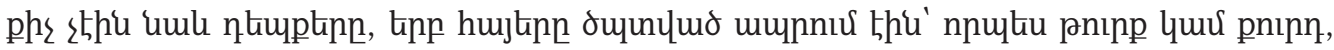

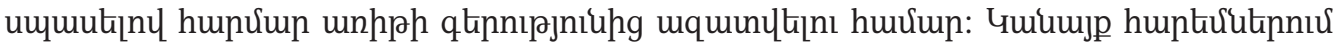

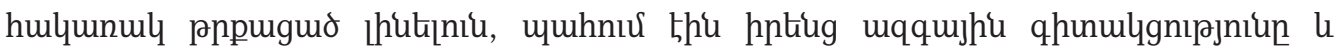

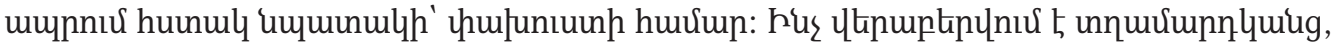

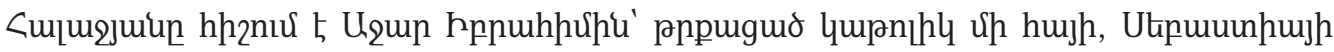

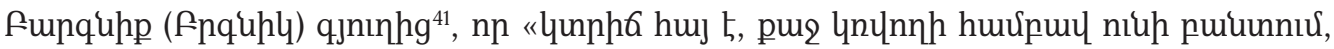

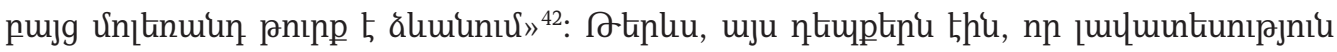

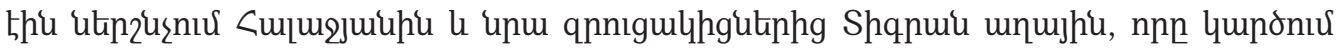

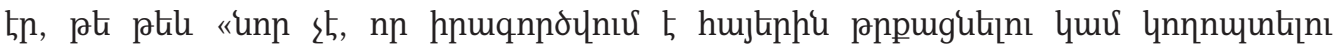

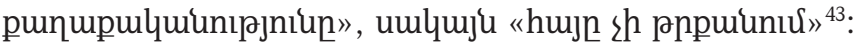

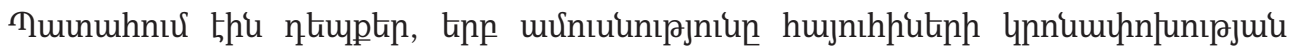

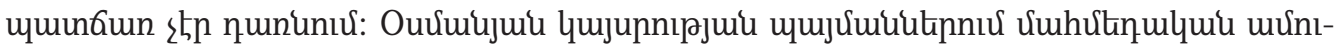

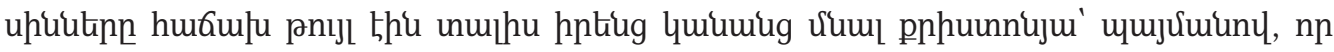

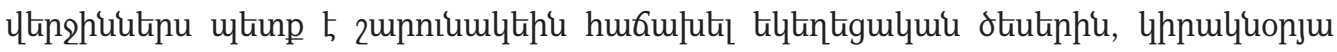

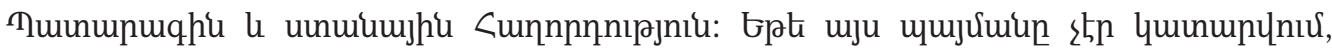

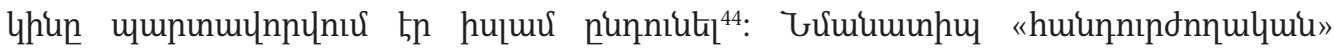

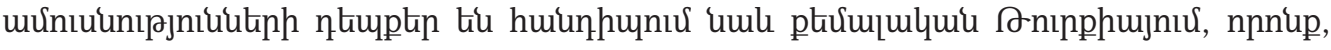

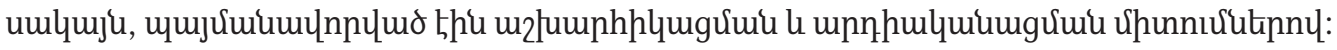

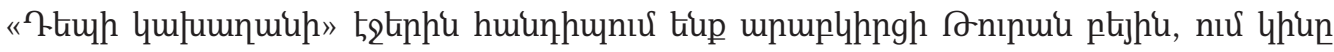

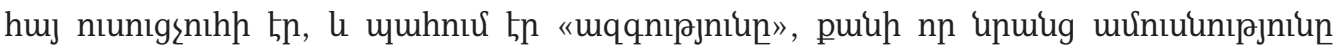

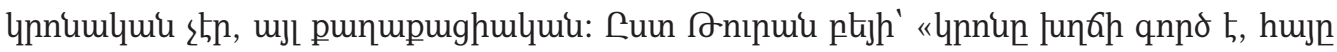

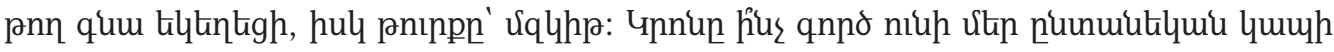

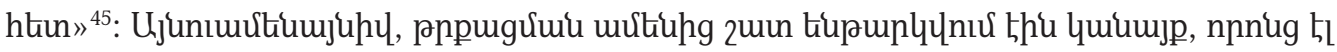

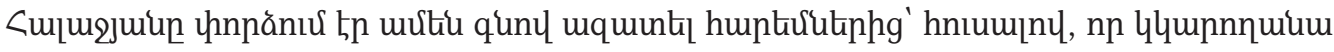

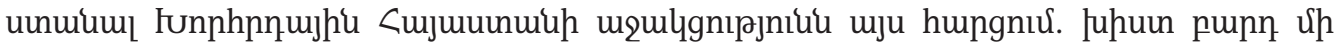
juinhn ${ }^{46}$ :

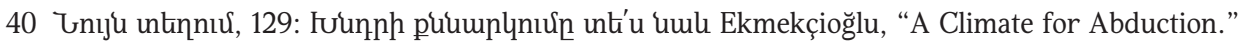

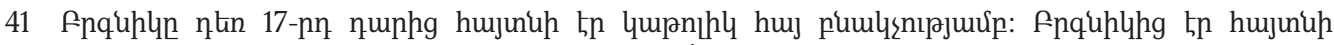

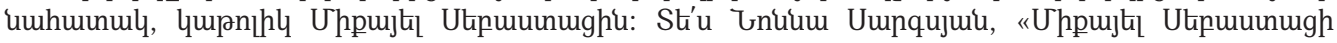
(Fnquhlgh) unp umhumuln", Fuiupkn Umintiumqunwiuh 24 (2017), 189-208:

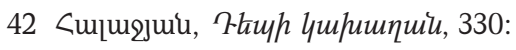

43 七nıju untønıu, 651:

44 Uju ưuuhu unt'u Emese Muntan, "Negotiating Catholic Reform: Global Catholicism and Its Local Agents in Northern Ottoman Rumeli (1570s-1680s),” (PhD diss., Central European University, 2021), 174-179.

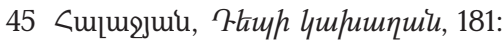

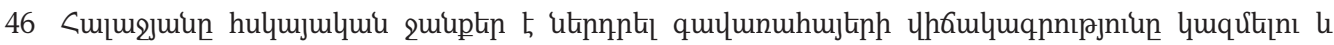

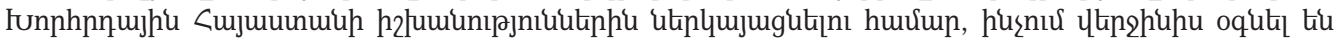




\section{Uppuquit unupuoph y hpurhn|untu}

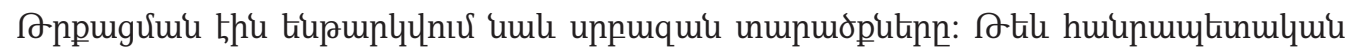

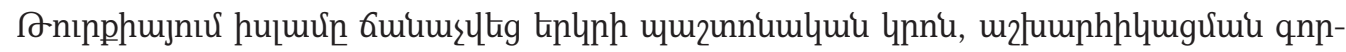

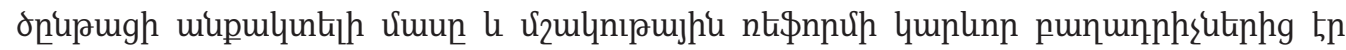

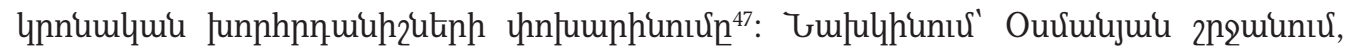

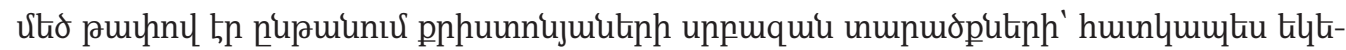

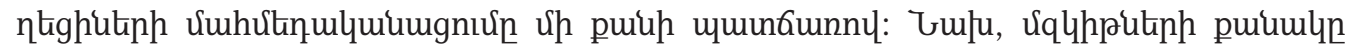

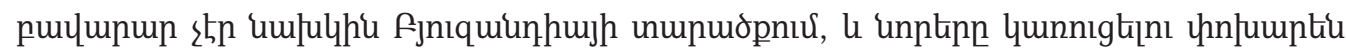

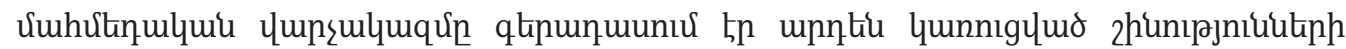

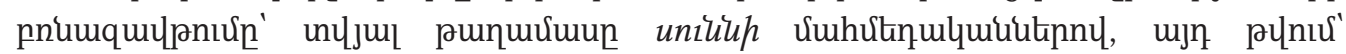

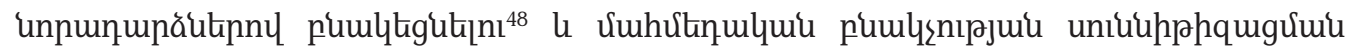

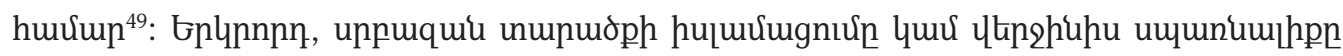

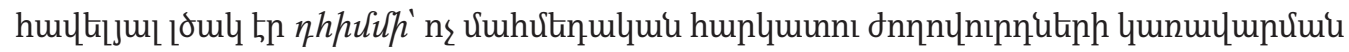

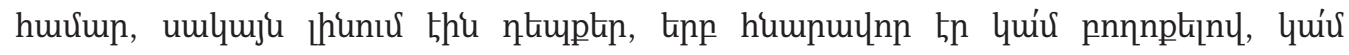

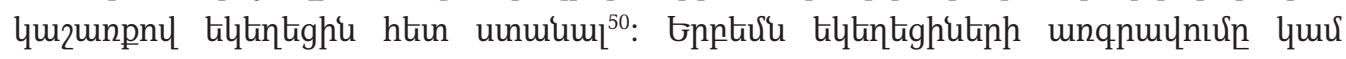

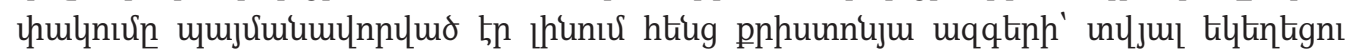

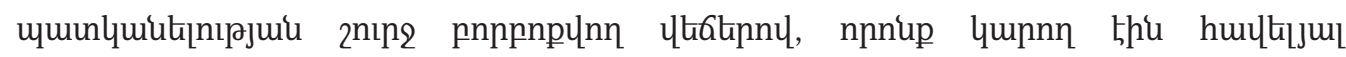

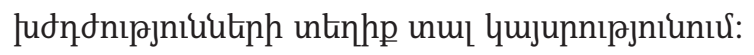

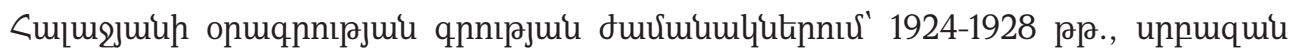

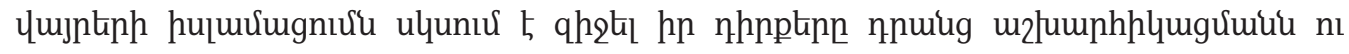

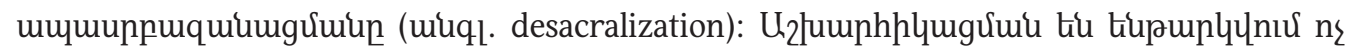

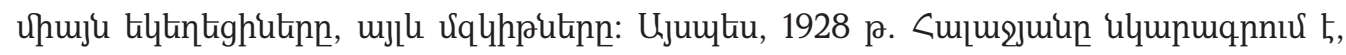

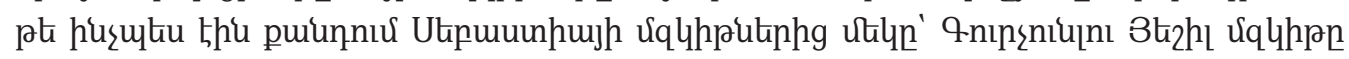

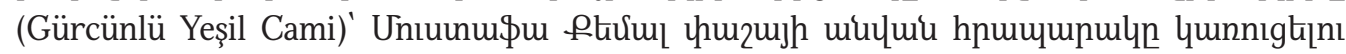

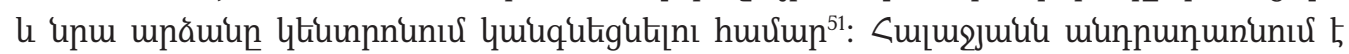

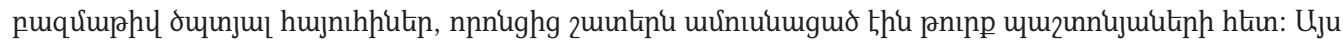

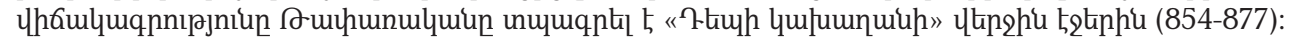

47 Zürcher, Turkey, 192-193.

48 Uju Uumuhu unt'u Marc David Baer, "The Great Fire of 1660 and the Islamization of Christian and Jewish Space in Istanbul," International Journal of Middle East Studies 36, no. 2 (2004): 159-181.

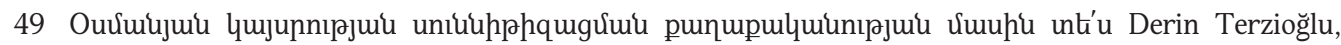
"How to Conceptualize Ottoman Sunnitization: A Historiographical Discussion," Turcica 44 (2012-2013): 301-338.

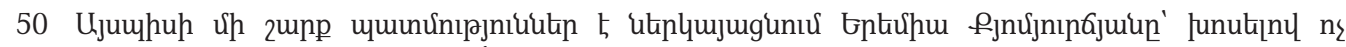

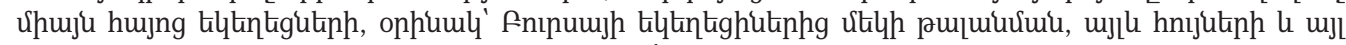

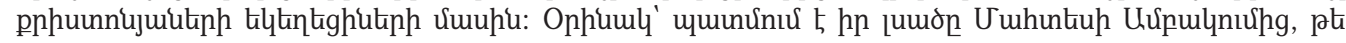

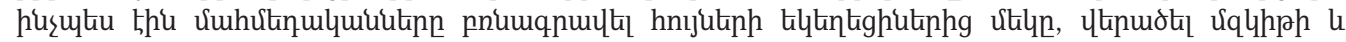

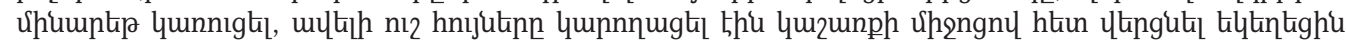

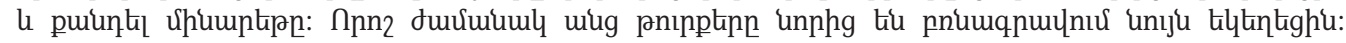

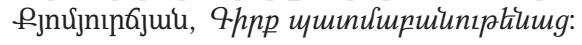

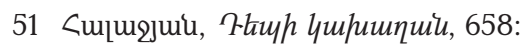




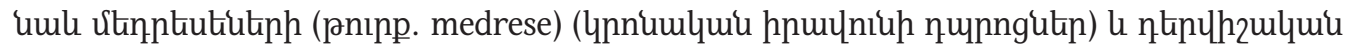

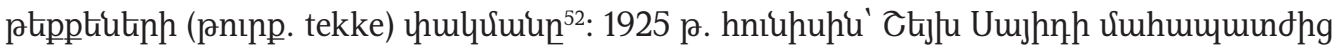

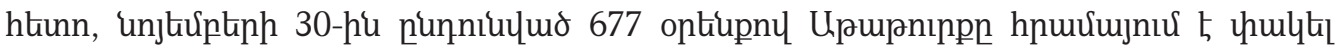

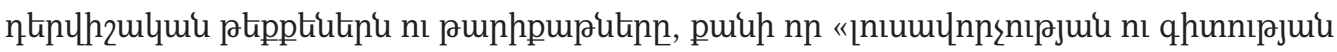

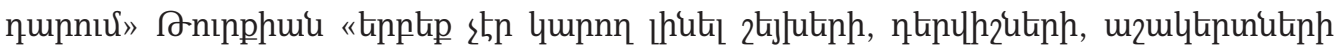

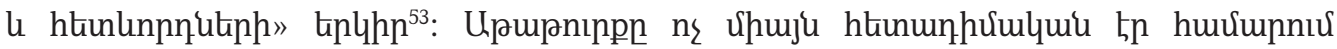

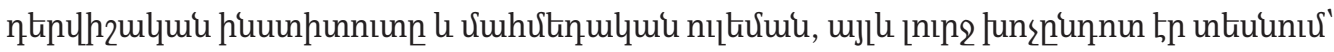

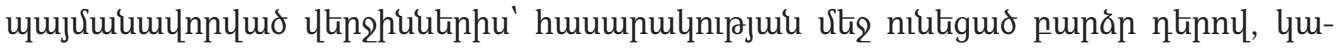

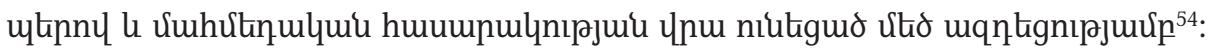

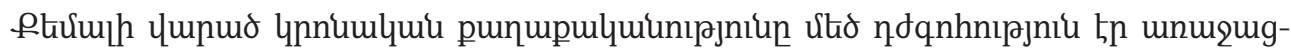

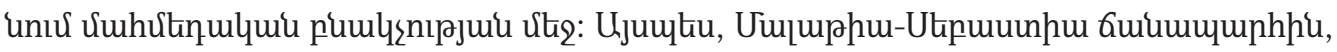

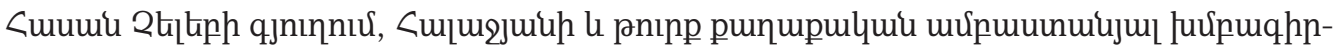

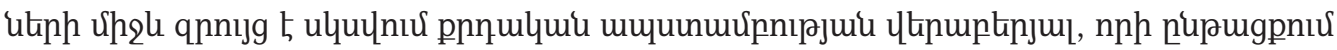

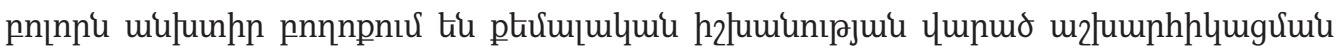

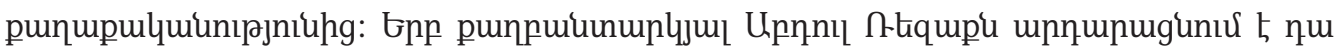

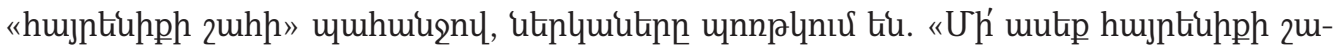

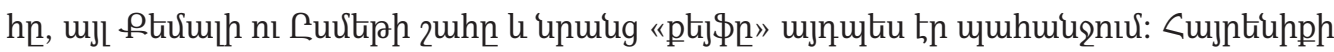

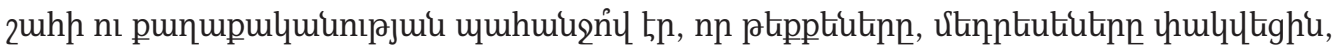

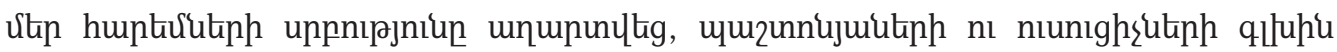

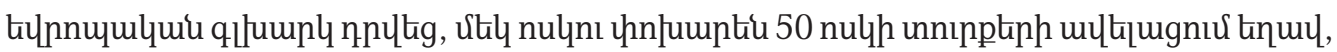

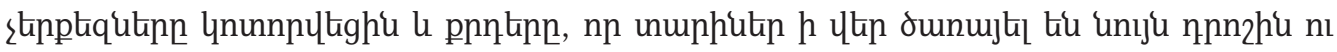

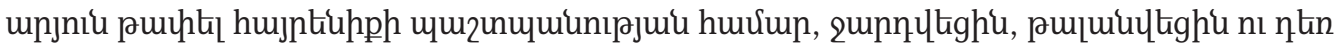

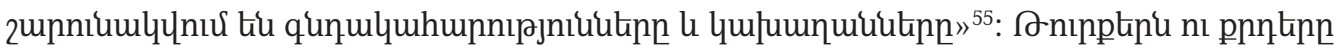

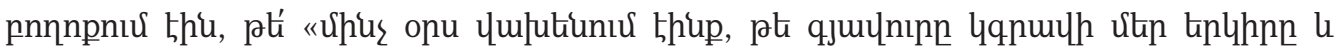

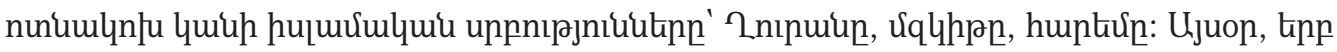

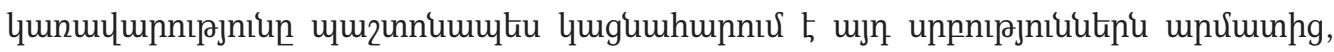

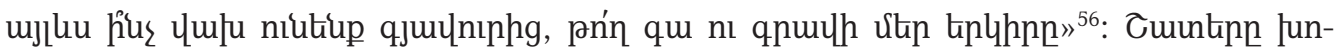

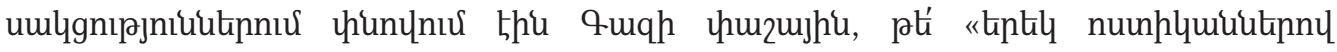

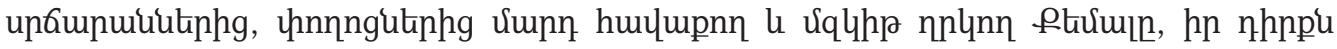

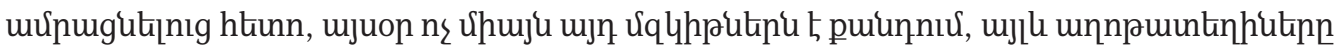
unnulumung 5 număunı ${ }^{3}{ }^{57}$ :

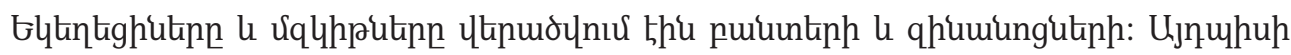

52 七nıu untฤnư, 290-295:

53 Üngör, The Making of Modern Turkey, 132-133.

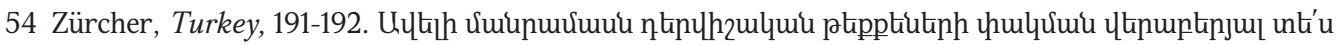
John Robert Barnes, "A Short Note on the Dissolution of the Dervish Orders in Turkey," The Muslim World 64, no. 1 (2007): 33-39.

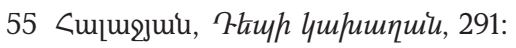

56 七nıju untønıx:

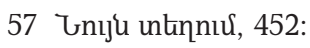




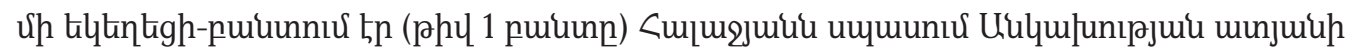

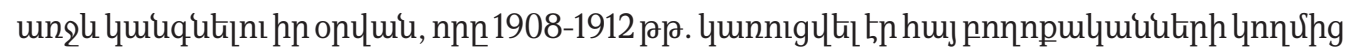

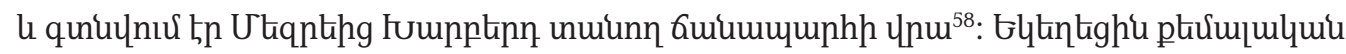

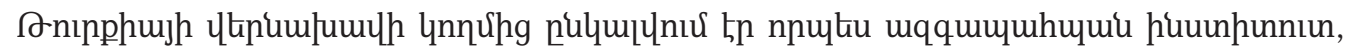

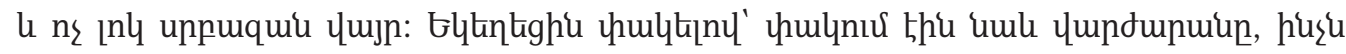

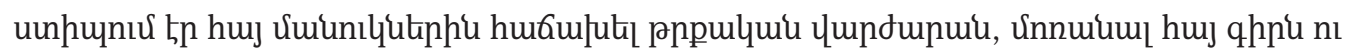

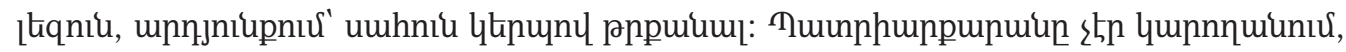

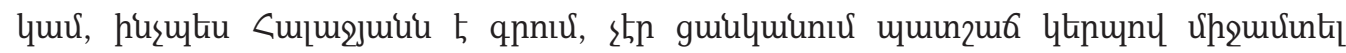

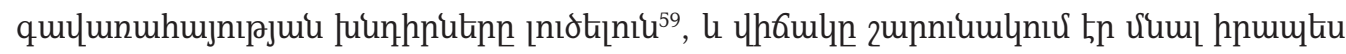
ппршц:

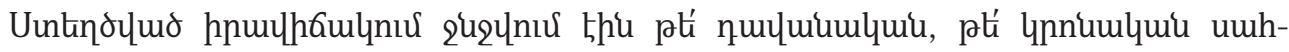

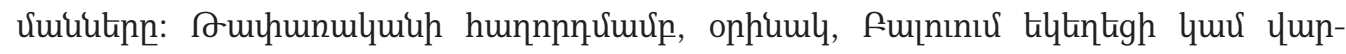

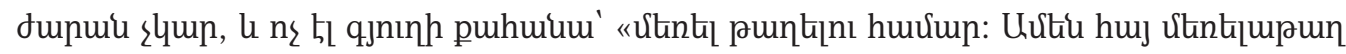

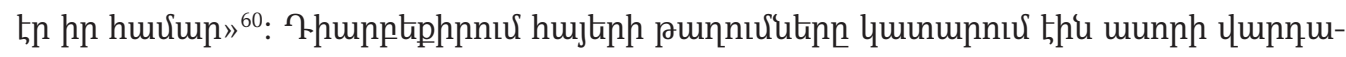

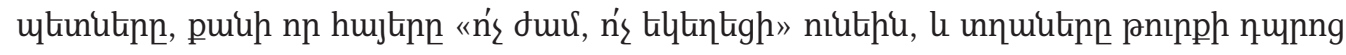

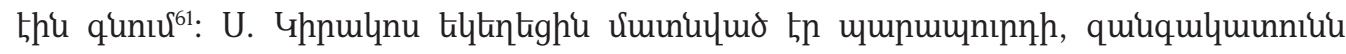

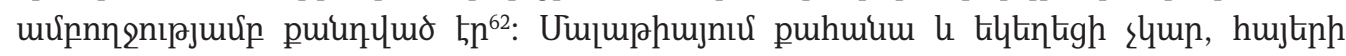

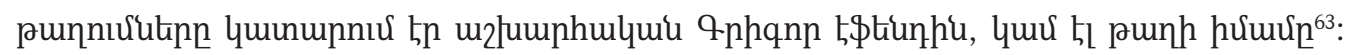

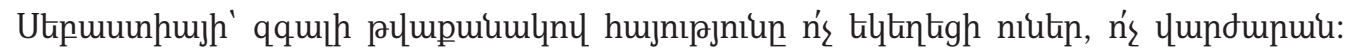

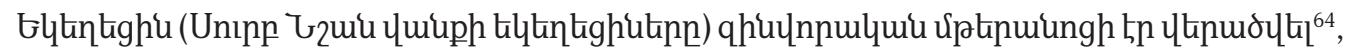

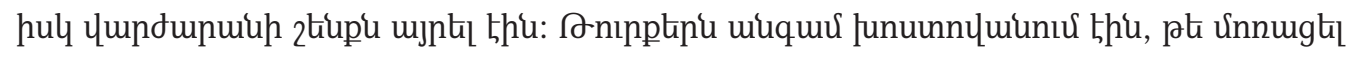

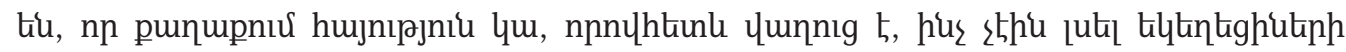
quiuquinh ămjų ${ }^{65}$ :

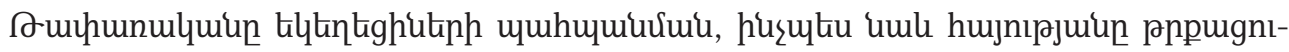

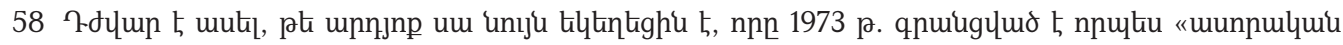

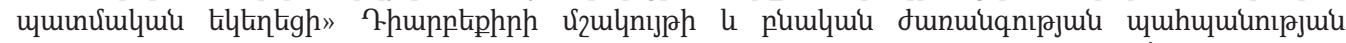

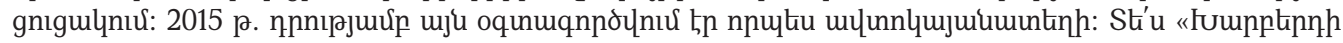

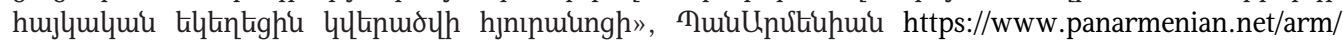

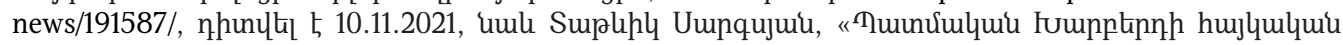

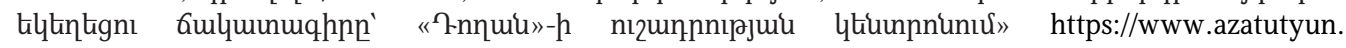
am/a/29610247.html, nhunцtil 5 10.11.2021:

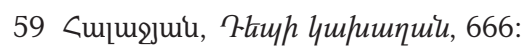

60 টnıju untnnıu, 861:

61 টnıju untinnuर, 157-158:

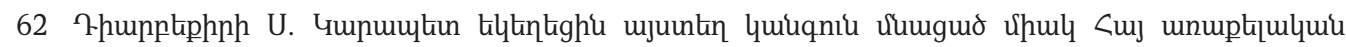

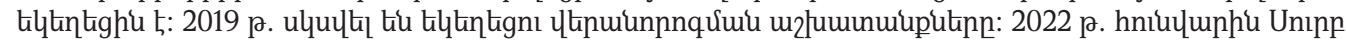

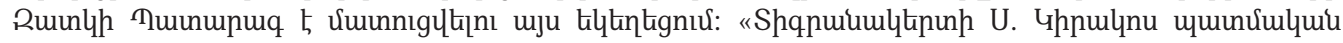

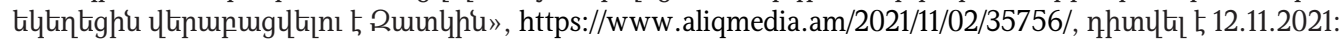

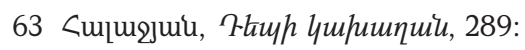

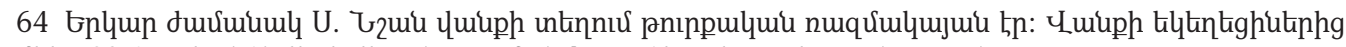

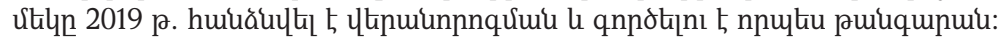

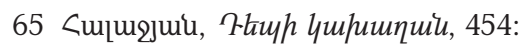




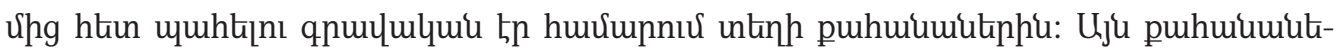

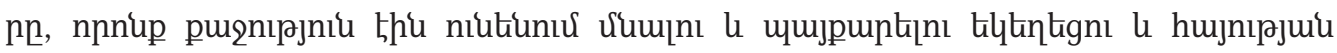

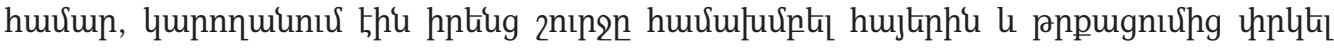

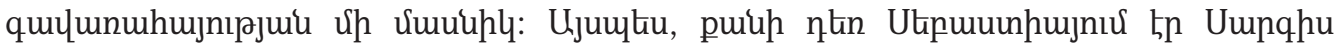

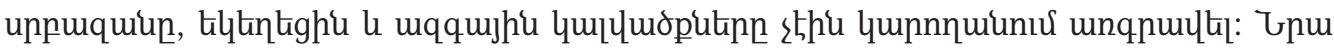

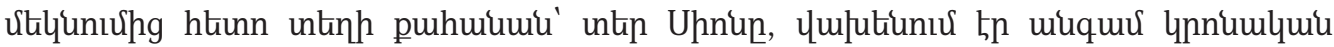

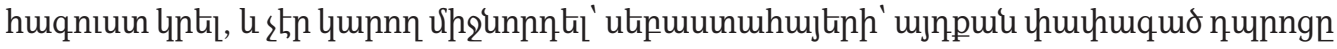

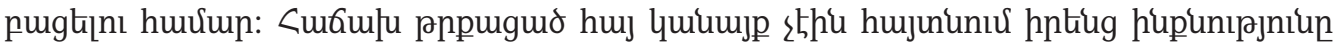

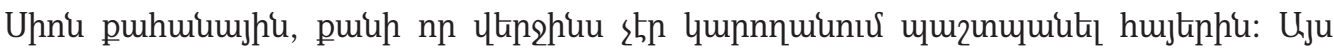

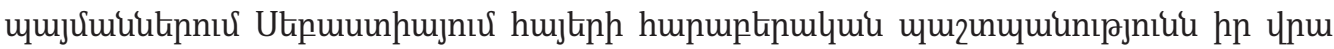

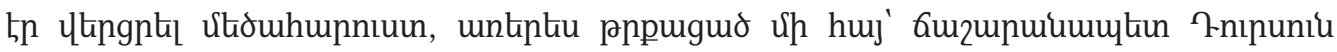

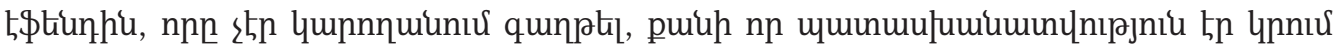

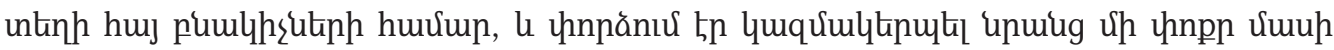

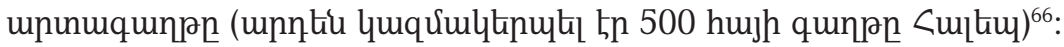

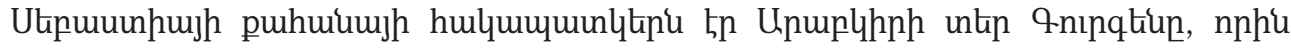

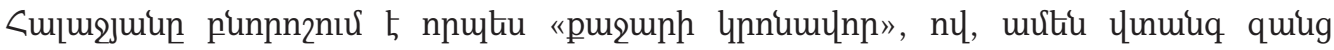

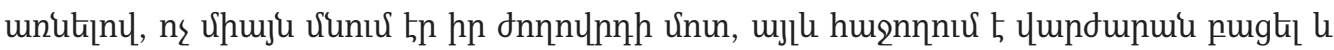
klykntighu qnuunuluhg wquintil:

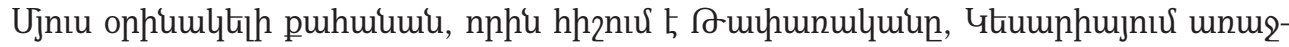

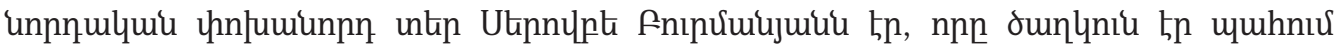

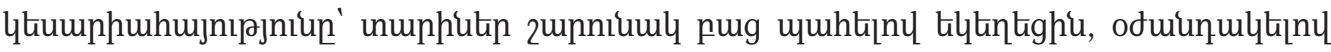

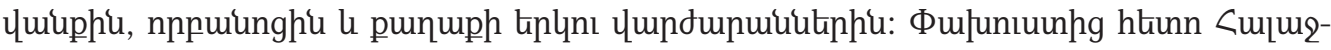

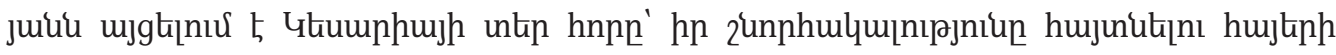

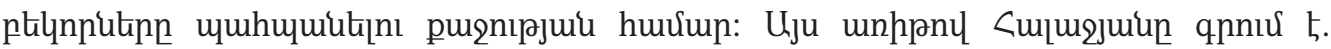

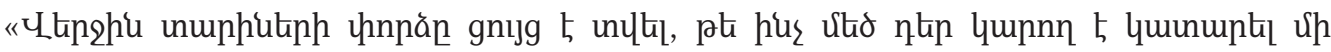

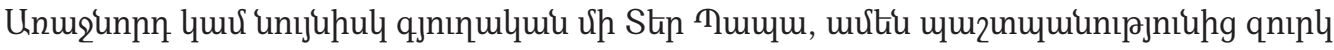

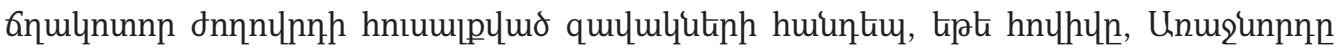

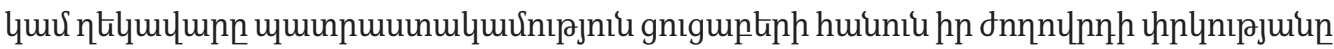

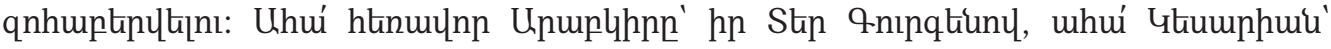

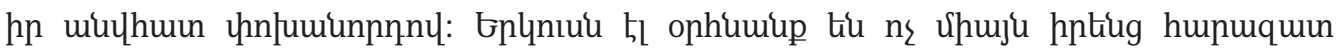

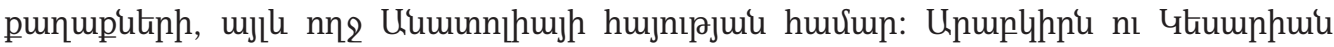

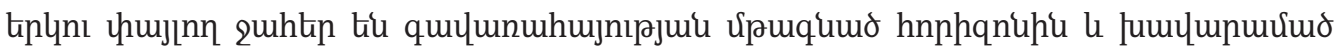

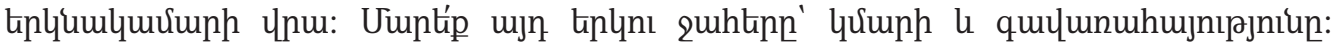

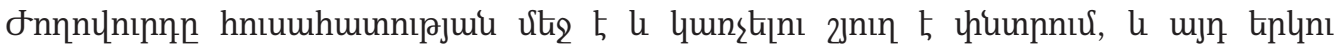

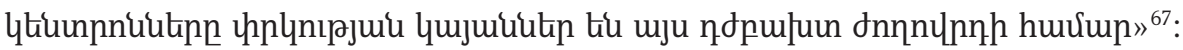

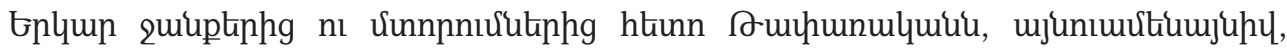

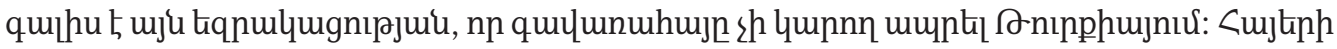

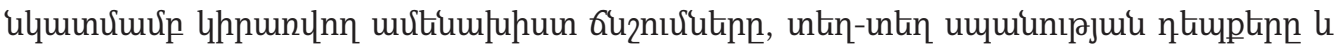

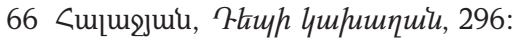

67 七nıju untฑnıu, 547: 


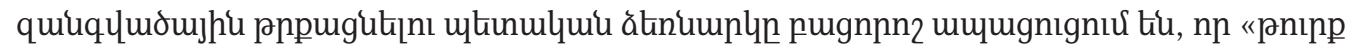

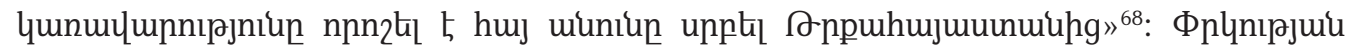

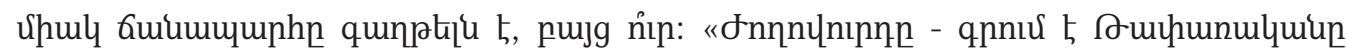

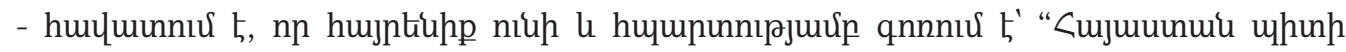

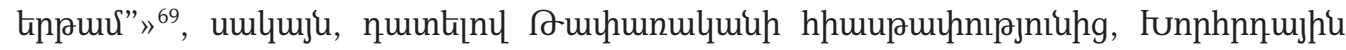

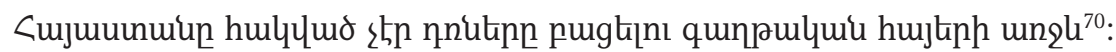

\title{
GEVORG HALAJYAN'S DIARY “TO THE GALLOWS” AS A PRIMARY SOURCE ON TURKIFIED ARMENIANS DURING AND AFTER THE ARMENIAN GENOCIDE
}

\author{
Anna M. Ohanjanyan \\ Matenadaran, Armenia
}

\section{SUMMARY}

Gevorg Halajyan's (Taparakan) diary-memoir was published in the USA yet in 1932, but it has not been decently studied and systematized. This extensive work is an invaluable source about the Turkification and assimilation of Armenians in several provinces of Western Armenia in 1924-1928. To stand before the Independence Tribunal of Kemalist Turkey, Halajyan had to travel to Adana, Diyarbakir, Kharberd, Malatya, to be eventually imprisoned in the jail of Sebastia. Halajyan wrote down whatever he eye-witnessed and heard of about the conversion and assimilation of the Armenians in the provinces. Later he escaped from prison to Bulgaria and then to America.

This article analyzes the data Halajyan left about Turkified Armenians, as well as discusses the issue of desacralization of churches and chapels during the Armenian Genocide. It also singles out Turkification cases, forms, and mechanisms to compare them with the mechanisms of Islamization in the Ottoman period to reveal not only the similarities but, first of all, the differences, particularly, due to the concept substitution.

Key words: Turkification mechanisms, Islamization, conversion, the rebellion of Sheikh Said, Istiklal, Armenian Genocide.

\footnotetext{
68 টnıju unknnıu, 546.

69 tnıju untinnư, 509:

70 Єnıju untinnıu, 547
} 


\title{
ДНЕВНИК ГЕВОРГА АЛАДЖЯНА “НА ВИСЕЛИЦУ” КАК ПЕРВОИСТОЧНИК О ТЮРКИЗИРОВАННЫХ АРМЯНАХ ВО ВРЕМЯ И ПОСЛЕ ГЕНОЦИДА АРМЯН
}

\author{
Анна М. Оганджанян \\ Матенадаран, Армения
}

\section{PE3ЮME}

Дневник-мемуар Геворга Аладжяна (Тапаракан) был издан в США еще в 1932 году, но не был должным образом изучен и систематизирован. Этот обширный труд является бесценным источником о тюркизации и ассимиляции армян в нескольких провинциях Западной Армении в 1924-1928 годах. Чтобы предстать перед Трибуналом Независимости кемалистской Турции, Аладжян должен был отправиться в Адану, Тигранакерт или Диярбакыр, Харберд, Малатию, чтобы в конечном итоге оказаться в тюрьме Себастии. Аладжян записал все, что видел и слышал об обращении и ассимиляции армян в провинциях. Позже он сбежал из тюрьмы в Болгарию, а затем в Америку.

В статье вкратце проанализированы данные, оставленные Аладжяном о тюркизации армян, десакрализация церквей и часовен во время Геноцида армян. Выделены случаи, формы и механизмы тюркизации, чтобы сравнить их с механизмами исламизации в период Османской империи с целью выявления не только сходств, но, прежде всего, различий, в частности, из-за подмены понятий.

Ключевые слова: механизмы тюркизирования, исламизация, обращение в ислам, восстание шейха Саида, Истикляль, Геноцид армян.

\section{REFERENCES}

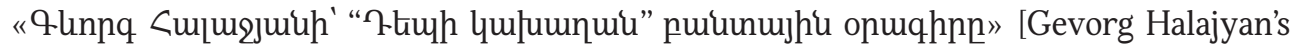
Jail Diary “To the Gallows”], https://www.aravot.am/2015/03/05/548207/;

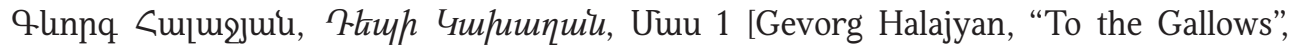
Part I], https://www.youtube.com/watch?v=qx90j19qWuc;

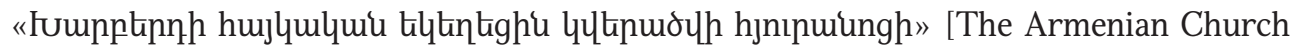
in Kharberd will be Turned into a Hotel], https://www.panarmenian.net/arm/news/191587/;

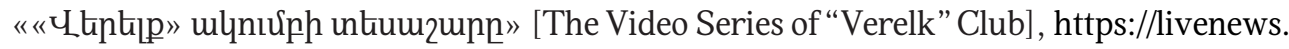
am/press/tag/qunnq-hulüjuu/;

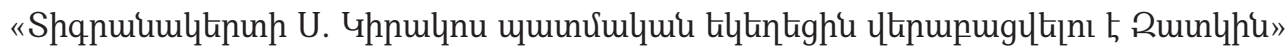
[Saint Kirakos Historic Church of Tigranakert will be Reopened on the Easter Feast], https:// www.aliqmedia.am/2021/11/02/35756/;

Halajyan, Gevorg. «Copu unniun» [My Father's Home]. Hayreniq 121, no. 1, (1932): 35; 


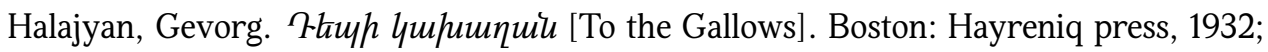

Halajyan, Gevorg. Fknuhuh mqquqnuluiu ujnıрknn (Utiptiumqhn) [Ethnographic Materials Concerning Dersim (typewritten)]. Archive of the Institute of Archeology and Ethnography of NAS RA, Folder nr. 5a (unpublished);

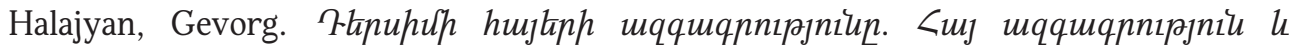
puiumhjniunipjniu: Zjnipkn 4 niunilumunnnipjniuiktn, h. 5 [The Ethnography of the Armenians of Dersim. Armenian Ethnography and Folklore: Materials and Studies, vol. 5]. Yerevan: Arm SSR Academy Sciences press, 1973;

Nshanean, Hakob (ed.). Juu\{uiumquqnnıphiu [Chronology]. Jerusalem: St. James' press., 1915;

Pepanyan, Artsrun (ed.). Tkuһ чщишұшiu [To the Gallows]. Yerevan, 2014;

Qyomyurchean, Yeremia Ch'elebi. Ahpp uminumpuiunıpkuing [Book of Historiographies]. Mekhitarist Library of Venice, MS 509 (unpublished);

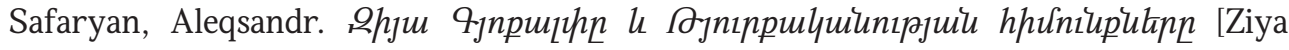
Gyökalp and the Basics of Turkism]. Yerevan: YSU Press, 2012;

Sargsyan, Nonna. "Uhpujkl Utpuuunugh (fnquhlgh) unn uwhuunulp" [The Neo-Martyr Miqayel of Sebastia (Brgnik)]. Banber Matenadarani 24 (2017): 189-208;

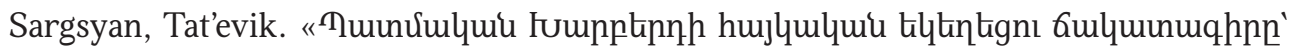

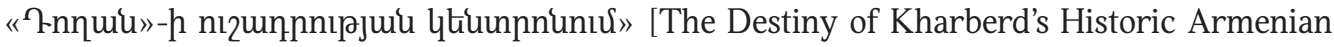
Church at "Doghan's" Attention], https://www.azatutyun.am/a/29610247.html.

\section{Ctiphumuh ưunitu \\ About the Author \\ Об авторе}

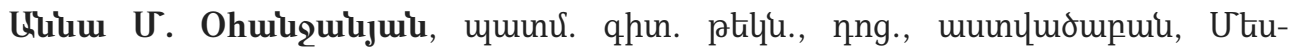

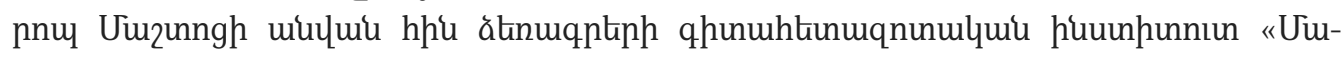

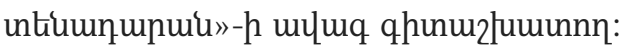

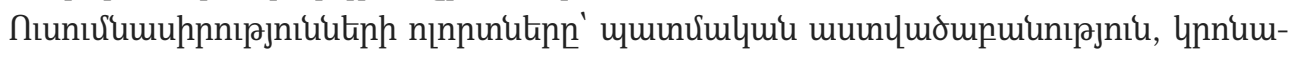
qhunnıpjniu:

Ll. unuunh huugt` annaohanjanyan@gmail.com

Anna M. Ohanjanyan, PhD in History, Associate Professor, Senior researcher at the Institute of Ancient Manuscripts after Mesrop Mashtots "Matenadaran."

Research fields - Historical Theology, Religious Studies.

E-mail: annaohanjanyan@gmail.com

Анна М. Оганджанян, канд. ист. наук, доцент, исследователь богословия, старший 


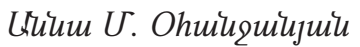

научный сотрудник научно-исследовательского института древних рукописей имени Месропа Маштоца “Матенадаран.”

Область исследований - историческое богословие, религиоведение.

Эл. почта: annaohanjanyan@gmail.com 